\title{
CALLING THE TANIWHA: MANA WAHINE MAORI AND THE POETRY OF ROMA POTIKI
}

\author{
By Kelly Lambert
}

A thesis presented in partial fulfilment of the requirements of the degree of Masters of Arts in New Zealand Literature of Victoria University of Wellington.

April 2006 


\section{ACKNOWLEDGEMENTS}

First and most importantly, warm thanks and aroha to my supervisor, Alice Te Punga Somerville, for all of her help with the production of this thesis. She has constantly challenged me to think and to question everything I read and wrote and she was gracious and giving with her time and knowledge. I also sincerely thank her for the various other roles she undertook, as motivator, cheerleader, mentor and friend - her contribution has been immeasurable. I would also like to thank Lydia Wevers, Paul Millar, Jane Stafford and James Meffan for their inspiration, challenges and general help that was forthcoming throughout the entire length of study for this thesis. I also thank the Stout Research Centre, and those responsible for the establishment of the Master of Arts Degree in New Zealand Literature in 2005 for the establishment of a degree that centres the importance of Aotearoa New Zealand literature. Thanks too to Maria Bargh, Chadwick Allen and Teresia Teaiwa for their wonderful help that enabled me to clarify and work through the positions I have taken in this thesis and for their personal encouragement. And finally, thanks to Claire Deegan and Angela Roskam-Parker for their friendship and company on this long and rewarding journey as inaugural students of the MA in New Zealand Literature. 


\begin{abstract}
This thesis aims to explore the implications of reading the poetry of Roma Potiki with some of the critical writing about Mana Wahine Maori. At the intersections between the creative and the critical writings, I produce a grouping of literature that I name 'Mana Wahine Maori poetry in English'. Specifically, I contend that combining the kaupapa of Mana Wahine Maori scholarship with the poetry of Roma Potiki, and other Maori women poets, results in new readings of all the texts involved that are rich in complexities and multiplicities. In Chapter One I explain the choice of Roma Potiki's poetry as poutokomanawa for this thesis and briefly introduce some of the issues surrounding genre, canon-making and naming for Mana Wahine Maori poetry in English. Chapter Two illustrates the whakapapa of Mana Wahine Maori critical writings and explores the implications of the 'Mana' in Mana Wahine Maori poetry in English. Chapter Three considers the 'Wahine Maori' of Mana Wahine Maori poetry in English, both by examination of 'Wahine' in its New Zealand context, and by reference to a selection of Black American, Native American and First Nations, Australian Aboriginal and feminist literary critical writings. Chapter Four supports the pluralist nature of Mana Wahine Maori poetry in English by specific reference to Iwi/Hapu/Whanau contexts, urban wahine Maori contexts and wahine takatapui contexts. Finally, Chapter Five examines whether Mana Wahine Maori poetry in English is still a productive grouping when reading the works of not only other wahine Maori poets, but other wahine Maori writers generally, and I use the writings of Keri Hulme to investigate this. Therefore, I argue that naming this diverse collection of writing 'Mana Wahine Maori poetry in English' enables new kinds of readings that admit and debate the multiplicities inherent in all of these works.
\end{abstract}




\section{ConTENTS}

CHAPTER 1: $\quad$ You think people don't know what you do

$\operatorname{Pg} 5$

CHAPTER 2: $\quad$ I have watched you getting people

$\operatorname{Pg} 22$ to agree to things they don't understand

CHAPTER 3: $\quad$ Put up with your clever bullying which passes as 'being political'

CHAPTER 4: $\quad$ And in the howl of a cleansing wind and the surge of powerful currents you will be carried to meet your creation.

CHAPTER 5: $\quad$ It is you who called the taniwha and you who will have to work for release.

CHAPTER 6: $\quad$ Drink enough blood to gather strength... 


\section{YOU THINK PEOPLE DON’T KNOW WHAT YOU DO}

The enigmatic epigraph to this introductory chapter is a line from Roma Potiki's poem "The Decision of the Taniwha". Its purpose here is to illustrate the illuminative function of this thesis: that is, it aims not to uncover/recover the work of an understudied poet ${ }^{1}$, but to read that work in a new light. The aim of this thesis is to explore the implications of reading Roma Potiki's work alongside of some of the critical writing about Mana Wahine Maori ${ }^{2}$. To this end, I focus on the production of a body of literature that I name 'Mana Wahine Maori Poetry in English'. This body acts as an intersection between Maori women's poetry and a large critical discourse centred on Mana Wahine Maori. Specifically, I contend that combining the kaupapa ${ }^{3}$ of Mana Wahine Maori scholarship with the poetry of Roma Potiki results in richly multidimensional and valuable new ways of looking at both of these areas. Therefore, to term her poetry an example of Mana Wahine Maori poetry in English is the most

\footnotetext{
${ }^{1}$ Which would ignore the significant place her poetry already occupies and adjudge the poetry's importance to be solely related to the number of critical articles about it. Clearly, this would be a reductive approach.

${ }^{2}$ Words in Maori with a long vowel sound are published in a variety of ways - with a macron, with a double vowel, or with just the single, unmarked vowel. While reasons for this difference are often based on dialectical differences, in this thesis the single, unmarked vowel will be used for the simple reasons that some versions of text editing programs - including those that I have access to - are unable to support the representation of macrons.

${ }^{3}$ While aware of the confusion that may be caused by the use of this word in future chapters to describe a separate Maori critical methodology, Kaupapa Maori Research, after a long consideration of alternatives, it was apparent that this was the most appropriate descriptor for this topic. The word "principles" was considered, but eventually dismissed as being too prescriptive, resulting in an inappropriately, and prematurely, closed category. Others were mooted: A way of looking? A set of questions? A theory? A framework? Tikanga?, However, it was kaupapa that was closest in meaning to what I was trying convey. As an additional note, I will not be providing either a glossary or in-text translation for the majority of words in Maori in this thesis, except for when the full impact of their meaning requires investigation. This is because (a) I believe they are well understood in common parlance, and if not, there are many Maori-English dictionaries that are widely and easily accessible; (b) this thesis aims to hold a wahine Maori audience at its centre - to translate such common Maori words into English would, I feel, signal that its true intention was to speak to a different audience entirely. In addition, this is a conscious decision on my part not to muddle Maori concepts with incomplete or inadequate translations into English. Eileen Clarke records Margaret Mutu's example of the common but inappropriate translation of 'kaitiakitanga' as 'stewardship': "the original meaning of stewardship is to guard someone else's property": clearly, this is completely at odds with Maori concepts regarding land, and the belief that our relationship to Papatuanuku precludes any form of legal ownership. Eileen Clarke, "The Taniwha's exile: the exclusion of Maori women from environmental policy and decision-making in Aotearoa/New Zealand," Hecate 30.1 (May 2004): 119-140.
} 
constructive and appropriate way to admit and debate the multiplicities inherent in her work. The dialogue created by the interaction between her poetry and Mana Wahine Maori scholarship not only provides insights into both, but in the resulting body of literature, also produces something new.

Roma Potiki is of Te Aupouri, Te Rarawa and Ngati Rangitahi. She was born in 1958, in Lower Hutt, and currently lives in Paekakariki. Although I focus on her work as a poet in this thesis, she is a multi-creative artist: she is well-known as a theatre playwright, director, producer and actor; she is also a visual artist and arts coordinator and commentator. She has published three collections of poetry to date: Stones in Their Mouths $(1992)^{4}$; Shaking the Tree $(1998)^{5}$ and Oriori: A Maori Child is BornFrom Conception to Birth (1999) ${ }^{6}$, the latter of which was produced in collaboration with visual artist Robyn Kahukiwa, and her poetry has also appeared in a number of anthologies.

The choice of Roma Potiki's poetry as the poutokomanawa for this thesis was a decision based on a number of factors. Firstly, as a Maori woman I felt a personal identification with many of her poems, and was keen to explore the reasons for that identification further. Secondly, though perhaps related to the first, I was moved by the power of her writing. I knew that this was complex, multilayered poetry, and was bemused by the reviewers who referred to its 'simplicity': could they not see what was happening beneath the surface of her words? ${ }^{7}$ Thirdly was what I perceived as a

\footnotetext{
${ }^{4}$ Roma Potiki, Stones in her Mouth (Tamakimakaurau, NZ: IWA, 1992).

${ }^{5}$ Roma Potiki, Shaking the Tree. (Wellington: Steele Roberts, 1998).

${ }^{6}$ Roma Potiki, and Robyn Kahukiwa, Oriori: a Maori Child is Born: From Conception to Birth. (Auckland: Tandem, 1999).

${ }^{7}$ For example, Tom Weston in the Press and Miranda Johnson in New Zealand Books. These particular reviews and others like it will be examined further in chapter two. Tom Weston, "Poets who seek
} 
curious visibility/invisibility in relation to Roma Potiki's poetry, vis-à-vis her other activities as a playwright, director, artist and so on. Although Potiki has published three collections of poetry, with individual poems appearing in a number of other publications, my first encounter with her poetry was in a post-graduate course at Victoria University entitled "Women Poets and the Canon". Despite a reasonable number of reviews of each collection ${ }^{8}$, there has been very little critical investigation of her work. ${ }^{9}$ During my studies for this course, I also observed this same relative visibility/invisibility in regard to the poetry of two other Maori women, Keri Hulme and J.C. Sturm. Both women were 'well known' public figures, but, arguably, not for their poetry. Hulme's 'visibility ${ }^{10}$ was in relation to her award-winning novel the bone people, while Sturm's was both as the first Maori woman to publish a collection of short stories - House of the Talking Cat - and her marriage to the poet James K Baxter. Although Hulme and Sturm had, like Potiki, published several collections of poetry each, their poetry was often placed in a secondary position when critical attention was paid to their work as a whole. As a result of my strong curiosity as to why this was so, this thesis was originally to focus on the poetry of Potiki, Hulme and Sturm as both visible, yet invisible poets. On deeper investigation however, it became clear that these three were not the only Maori women poets in such a position, and so

truth," Rev. of Beyond by Brian Turner and Stones in Her Mouth, by Roma Potiki, Press 1 May 1993: Sup10. Miranda Johnson, "Yielding to the Surges," Rev. of Shaking the Tree, by Roma Potiki, and The Paper Road, by Julie Leibrich, and the ordinary magic, ed. Vivienne Plumb, New Zealand Books: A Quarterly Publication 8.4 (Oct. 1998): 17.

${ }^{8}$ Four for Stones in Her Mouth, five for Shaking the Tree, and four for Oriori: A Maori Child is Born. A non-exhaustive investigation of the reviews for others poets in Auckland University's online "Literature File", which shows that four/five reviews per poetry collection is quite typical, is the basis for my use of the word "reasonable". New Zealand Literature File, The University of Auckland Library, 15 Apr. 2006 < http://www.library.auckland.ac.nz/subjects/nzp/nzlit2/authors_az.htm >.

9 And from personal experience, despite completing five years of high school English classes at Tauhara College in Taupo, four years of undergraduate English literature at Canterbury University and three postgraduate English literature courses at Victoria prior to this, the "Women Poets" course was the first time that I became aware of Roma Potiki as a poet. Her name was not unknown to me however, as I had previously heard of her plays and as a curator.

${ }^{10}$ By 'visibility', I refer to a rather narrow definition comprising published attention (including book reviews, critical articles, interviews, etc) and institutionalized attention (i.e. the number of literature courses that include their work). 
due to a restricted word count I chose to focus mainly on the original inspiration for this project - the poetry of Roma Potiki. Finally, in Potiki's work I also found an engagement with many of the same issues that Mana Wahine Maori theorists were grappling with, and thus saw a possibility for exploring the intersections between these areas.

Genre is clearly a significant issue here: the decision was made to concentrate on Potiki's poetry, rather than her writing in general, because of my belief that her poetry - and the poetry of other Maori women - is understudied in relation to her/their other creative work. However genre is not the major focus of this thesis and so the aim of the following section is merely to clarify the decision to choose to focus on only the poetry of Roma Potiki, rather than an in-depth interrogation of issues surrounding poetry as a genre. Firstly though, there is a broader context that needs to be acknowledged before addressing any questions of genre: that there is a chronic lack of study of all Maori texts in English at all educational institutions. ${ }^{11}$ I believe that

\footnotetext{
${ }^{11}$ The exceptions to this may be wananga and kura kaupapa Maori, but clearly reo would be a factor in such cases. For example, at Victoria University of Wellington, at which I am a Masters student, in 2006 the English department offers BA (Hons) students a choice of courses including eight medieval literature courses (although only five are on offer for 2006), seven renaissance literature courses (only one of these is on offer for 2006), and at least 19 other courses (of which eleven are on offer for 2006). Of these 19 other courses, only four focus on New Zealand literature, and only three of those are offered for the 2006 academic year. These three courses are ENGL 423: Mansfield and Friends; ENGL 420: New Zealand fiction for children; and ENGL 453: Drama and Theatre in Aotearoa New Zealand. None of these courses hold Maori literature at their centre. Although this preference for non-New Zealand, and particularly non-Maori literature seems marked, Victoria University actually has (in addition to Auckland University) the greatest number of postgraduate New Zealand literature courses among New Zealand universities. In comparison, Canterbury University, at which I was an undergraduate, offers its BA (Hons) students ten courses (eight in the 2006 academic year), of which only two - ENGL 425: The Novel since 1945: Contemporary Canadian and New Zealand Fiction; and ENGL 431: Young Adult Fiction - focus partly on New Zealand literature. Again, Maori literature is nowhere near the centre of these courses. It is particularly useful to look at the postgraduate courses, as it from such courses that most of this country's future English literature lecturers emerge; such students will then themselves go on to shape the courses, required readings and education of future students. Sources: English, Film, Theatre, Media Studies, Victoria University of Wellington, 15 Apr. 2006 $<$ http://www.vuw.ac.nz/seft/english/courses/index.aspx\#a400>.

Courses and Subjects: English, Canterbury University. 15 Apr. 2006

$<$ http://www.canterbury.ac.nz/courseinfo/GetCourses.aspx?type $=$ course\&value $=$ engl\&source $=$ course $>$.
} 
students should not be able to leave a New Zealand higher educational institution without having studied the work of Roma Potiki, Keri Hulme, J.C. Sturm, or any of the works of the many other Maori women poets. To be able to leave these institutions, or even to be able to leave a New Zealand secondary school without even being aware of the existence of these texts needs to be made far less likely.

To return to genre then, I think that it is most fruitful to talk about genre in terms of canon-making. That is, that no matter how we approach the issue of a 'canon of New Zealand literature', the discussion seems to continually revolve around the novel ${ }^{12}$. New Zealand literature courses offered at New Zealand Universities focus primarily, and even exclusively, on novels. Shelves in bookstores consistently offer far more novels than volumes of poetry. The Whitcoulls List - Top 100 Books in New Zealand, voted on yearly by the general public features no poetry whatsoever, though this list is not exclusively fiction-based: it includes non-fiction from categories such as autobiography, self-help, history and cooking. ${ }^{13}$ Print runs of first edition novels typically run in the thousands, first edition poetry in the hundreds - and there are many other examples. This canonicity in relation to genre has important implications for the poetry of Indigenous women and so, clearly, for the poetry of Roma Potiki. Already less likely to feature in New Zealand university English literature courses by virtue of being Maori (as illustrated in regard to postgraduate courses, but certainly

English: Faculty of Arts, University of Auckland, 15 Apr. 2006

$<$ http://www.arts.auckland.ac.nz/subjects/index.cfm?P=1738>.

${ }^{12}$ M.H. Abrams defines "literary canon" as:

...those authors who, by a cumulative consensus of critics, scholars, and teachers, have come to be widely recognized as "major," and to have written works often hailed as literary classics. These canonical writers are the ones which, at a given time, are most kept in print, most frequently and fully discussed by literary critics and historians, and most likely to be included in anthologies and taught in college courses...

M.H. Abrams, A Glossary of Literary Terms (Fort Worth: Harcourt Grace College Publishers, 1993) 19-20.

${ }^{13}$ Whitcoulls List - Top 100 Books in New Zealand, Whitcoulls. 1 Apr. 2006.

$<\underline{\text { http://www.whitcoulls.co.nz/top100.asp?storeurl=whitcoulls }}>$. 
just as true of undergraduate prescriptions), that these works are poetry means that Potiki's poems are even less likely to be a topic of discussion. However, for reasons which will be elucidated in the following chapters, this thesis is not an attempt to redress any imbalance in the attention paid to her poetry in particular, or the poetry of Maori women in general. Neither is it my intent to argue for the inclusion of Potiki's poetry into that amorphous mass 'the canon of New Zealand literature'. Both, as I will argue further, are negative positions from which both Roma Potiki and her poetry are positioned as 'victim' of some larger power, measured against a dominant 'norm'. Rather, this thesis begins from the more positive standpoint of exploring my own personal interests: a desire to know what a conversation regarding Potiki's poetry and Mana Wahine Maori scholarship would look like? Is there a point of intersection between them at which a grouping - Mana Wahine Maori poetry in English - might be identified? Is it productive, or even possible, to create such a grouping? My aim in this thesis is to start that conversation.

Having stated that I am not arguing admittance for Roma Potiki's poetry into the New Zealand literary canon, it is useful to look at how other Indigenous ${ }^{14}$ scholars have approached the issue of canons. In his book Red on Red: Native American Literary Separatism, ${ }^{15}$ the title of which explicitly sets out the agenda he is aiming for, Creek scholar Craig Womack argues that it is not only valuable to look toward Creek authors and their texts in order to understand Creek writing, but that it is vitally important to prioritize "Native voices"

\footnotetext{
${ }^{14}$ That is, the people Indigenous to a land; the first people to settle and live there, such as Maori in Aotearoa.

${ }^{15}$ Craig S. Womack, Red on Red: Native American Literary Separatism, (University of Minnesota Press: Minneapolis. 1999).

${ }^{16}$ Womack 7.
} 
...tribal literatures are not some branch waiting to be grafted onto the main trunk. Tribal literatures are the tree, the oldest literatures in the Americas, the most American of American literatures. We are the canon."

And:

We should not allow ourselves, through the definitions we choose and the language we use, to ever assume we are outside the canon: we should not play along and confess to being a second-rate literature.

Neither statement questions the act or, indeed, the utility of canon-making: Native American literature is definitely a part of some canon. What is interesting here is a seeming uncertainty about exactly which canon it is a part of. The first statement centres Native American literature in its own canon; it is the centre, because it is the only literature (in the Americas) old enough to be called 'the canon'. The second statement however, seems to hint at a less absolute definition of 'canon', while still centring Native American literature within such a category. Such uncertainty certainly does not negate the power or the intent of these statements though: the 'traditional' literary canon is unacceptable to Indigenous peoples. As a rejoinder to such exclusions, Anita Heiss illustrates the way that an Australian Aborigine literary canon - in particular, a Walpiri literary canon - positions Anglo-originated texts and their readers on the margins:

...the historical literary creativity of Aboriginal people who combine art and language to communicate stories to the broadest possible audience. For example, many Walpiri people cannot read Walpiri when it is written in the 
'English' style, but they can read the painted stories. By way of comparison, many Europeans could not read these paintings. ${ }^{17}$

Here the aim is not to fight back against exclusion by prescribing a different form of exclusion, but rather to step out of the debate surrounding the 'traditional' eurocentric canon by focusing on the acknowledgement or production of one's own canon instead (hence "Literary Separatism"). Is this the road that Mana Wahine Maori poetry in English should follow?

Some writers, however, question the existence of canons altogether. In another uncompromisingly titled book, Loose Canons: Notes on the Culture Wars, ${ }^{18}$ Black American literary academic Henry Louis Gates, Jr. begins with a literary whodunit: detective Sam Slade is hired to find out who controls canon-making. He discovers that it's all a set-up, designed to make money and glittering careers for some - editors, librarians, academics, publishers, book reviewers, teachers, $\mathrm{PhD}$ candidates - whilst keeping others out in the dark (or whilst keeping dark others out?): "If you're on this list, they teach your work in school and write critical essays on you. Waldenbooks moves you from the Fiction section to the Literature section." ${ }^{\prime 19}$ Despite this criticism of canon-making, Gates Jnr then goes on to discuss how he and other Black editors are proceeding with the creation of their own canon, a Norton Anthology of Black American writing. He admits the contradiction: "I am not unaware of the politics and irony of canon formation", ${ }^{20}$ but goes on to defend its necessity. He contends that all Black American writers have eventually benefited in some form from canons, and that

\footnotetext{
${ }^{17}$ Anita M. Heiss, Dhuuluu-Yala To Talk Straight: Publishing Indigenous Literature (Canberra: Aboriginal Studies Press, 2003) 25.

${ }^{18}$ Henry Louis Gates Jr, Loose Canons: Notes on the Culture Wars (Oxford: Oxford University Press, 1992).

${ }^{19}$ Gates 3-4.

${ }^{20}$ Gates,32.
} 
many would not have survived without the editors of these canons "marshalling evidence" to show that a Black literary tradition actually exists. ${ }^{21}$ It would seem then, the audience for whom these canons are intended are not mainly Black Americans arguably, many Black Americans would already be aware of their own literary inheritance. However, Gates differentiates his own canon-making as not trying to prove the existence of Black American writing, but simply to gather its "crucially central authors". ${ }^{22}$ This is yet a further example of some of the many problematics associated with the making of an alternative canon. If Mana Wahine Maori poetry in English were to follow this path, these issues, and others such as who gets to be in the new canon, would all need to be addressed. Because of such problems, and because of the inherent and perhaps unsolvable difficulties with making such judgements, canonmaking is not a useful exercise here and as such is not the aim of this thesis. Rather, I prefer Griselda Pollock's feminist approach to the canons surrounding art history:

...a shift from the narrowly bounded spaces of art history as a disciplinary formation into an emergent and oppositional signifying space we call the women's movement which is not a place apart but a movement across the fields of discourse... ${ }^{23}$

Thus, rather than a new canon, Mana Wahine Maori poetry in English too may most usefully operate as a 'movement across' literature, as the intersecting moment referred to earlier in this chapter.

The issue of naming is also an important factor in relation to the grouping Mana Wahine Maori Poetry in English: the naming of elements, symbols, etc that is the

\footnotetext{
${ }^{21}$ Gates 32.

${ }^{22}$ Gates, 32.

${ }^{23}$ My emphasis. Griselda Pollock, Differencing the Canon: Feminist Desire and the Writing of Art's Histories (London and New York: Routledge, 1999) 26.
} 
purpose of all literary criticism, and in this case, naming in Mana Wahine Maori criticism, as well as the naming of the grouping itself. The following examples are part of the critical milieu surrounding the issue of naming, and are some of the critics asking questions that are particularly productive for the purposes of this thesis. The examples I will focus on here are the many questions surrounding the method of naming used in library cataloguing systems. ${ }^{24}$ In an exposition on the Dewey Decimal System $^{25}$, Hope A Olson notes that, just as with all other systems of naming, “...it is constructed. Hence, it does not just passively reflect the dominant values of society in some neutral or objective manner, but selects those values for expression." 26 She refers to this as a "canonical interpretation of knowledge",27, controlling as it does the terms that may be used to access it. The implications for the mode of literary criticism used in this thesis is clear: if naming is indeed a "means of structuring reality" 28 , as Olsen contends, then what does it mean to name the poetic output of Roma Potiki as an example of Mana Wahine Maori Poetry in English? I will be illustrating that this naming creates an identity that centres Potiki's poetry in not only the Maori world, but the Wahine Maori world. In contrast, to name her poetry as an example of postcoloniality would be to centre a world that was colonized, and so for the purposes of this thesis, it is not as productive a structure as that of Mana Wahine Maori.

\footnotetext{
${ }^{24}$ There are many other such critiques and investigations of the process of naming, and its political significance. Edward Said's Orientalism is a seminal text which discusses the 'othering' of peoples via naming; there are also many texts that discuss the actual dispossession/colonisation performed through naming of space/geography, such as Paul Carter's The Road To Botany Bay and Derek Gregory's Geographical Imaginations:

...language was an instrument of physical colonization; that there is an important sense in which the landscape had to be differentiated through naming in order to be brought into an existence that was meaningful for the colonizers and within which they could frame their own actions.

Derek Gregory, Geographical Imaginations (Cambridge MA: Blackwell, 1994) 172.

${ }_{25}$ The cataloguing system preferred by many public and school libraries in New Zealand, for its apparent simplicity.

${ }^{26}$ Hope A Olson, The Power To Name: Locating the Limits of Subject Representation in Libraries (Dordrecht: Kluwer Academic Publishers, 2002) 2.

${ }^{27}$ Olson 28.

${ }^{28}$ Olson 4.
} 
Clearly, this is also a political issue of self-determination and self-development: ${ }^{29}$ "Because a library determines who has access to the knowledge it stores, it also determines who has access to the power in society". ${ }^{30}$ In their investigation of the of the impact of the Library of Congress cataloguing system ${ }^{31}$ on the naming of Maori, and in this case, Ngati Kahungunu and Te Waka o Takitimu resources, K. Irwin and W. Katene critique the way that traditionally interconnected Maori knowledge is split into Anglo-American subject classifications such as "Maori history", "Maori religion", "Maori education", and so on. ${ }^{32}$ Not only does this prevent Maori people from conceptualizing a subject search using Maori divisions of knowledge ${ }^{33}$, it makes it harder for us to access the knowledge that we seek at all. Irwin and Katene provide an example of this using the English translation for the word whaikorero - rhetoric as it appeared on the Victoria University library catalogue as evidence of a translation that many Maori probably would not use: "This does not mean that Maori people are incapable of thinking in Pakeha terms, but that for a Maori person, the way the Pakeha people have described 'whaikorero', is different from how a Maori would describe it." ${ }^{34}$ Judylyn S. Ryan describes an even direr situation in regards to African religious traditions:

The dearth of names, labels, terminology in the West and in the Western academy for describing this and other key aspects of Black peoples' lives in the diaspora, as on the continent, is intimately connected to the fact that the African cultural domain has been designated as the absence of culture, so that one need

\footnotetext{
${ }^{29}$ The meaning of the word 'political' as used here and in relation to Roma Potiki's poetry will be examined in depth later in the thesis.

${ }^{30}$ K.G. Irwin and W Katene, Maori People and the Library: A Bibliography of Ngati Kahungunu and Te Waka o Takitimu Resources (Wellington: Victoria University of Wellington, 1989) 16.

${ }^{31}$ The cataloguing system used by most university libraries for its apparent range and depth of subject areas.

${ }^{32}$ Irwin and Katene, Maori People and the Library 18.

${ }^{33}$ For example, Irwin and Katene point out that most related material is catalogued under the heading

"Maori", rather than under tribal names. Irwin and Katene, Maori People and the Library 20.

${ }^{34}$ Irwin and Katene 20.
} 
not assign any further definitions. This designation perpetuates both a "conceptual gap" and a "functional lexical gap". ${ }^{35}$

Certainly it is not bold to suggest that both these lexical and conceptual gaps also exist in Pakeha formulations of Maori culture: "Maori names do not always tidily translate into European methodologies". ${ }^{36}$ This is where a Maori formulation, such as Mana Wahine Maori, enables readings that other critical formulations do not. It allows for "the unnaming power of ambiguity". 37 That is, by refusing to provide concrete definitions and formulations, Mana Wahine Maori, and in turn the grouping Mana Wahine Maori poetry in English allow for the flexible potential of multiplicities in a work.

Despite its place in this thesis, the methodology of naming is not the key focus of this thesis: to make it key would be to centre a reactive position, to state that my aim is to work against those who have named the poetry of Maori women in the past. Such a position is untenable as it merely replays the binary opposition of 'me/us = victim' and 'you = oppressor'. Rather, the aim is to work from the more productive position of Mana Wahine Maori. Such affirmation can be found in Roma Potiki's poems themselves, such as "Maioha", which celebrates the birth of a Maori child, emphasizing the joy, rather than the difficulties it has been born into: "This chorus is no sad mourning, no slow parade. / I am so happy for you...// each breath exhales a future." ${ }^{38}$ In this thesis, taking the power to name back from the more Eurocentric

\footnotetext{
${ }^{35}$ Judylyn S. Ryan, Spirituality as Ideology in Black Women's Film and Literature (Charlottesville and London: University of Virginia Press, 2005) 34.

36 Jon Battista, "Nga Ahorangi," Hecate 23.1 (May 1997): 143-77.

${ }^{37}$ Powhiri Wharemarama Rika-Heke, "Margin or Center? "Let me tell you! In the Land of my Ancestors I am the Centre": Indigenous Writing in Aotearoa," English Postcoloniality: Literatures from around the world, eds. Radhika Mohanram and Gita Rajana.(Westport: Greenwood Press, 1996) 154.

${ }^{38}$ Potiki, "Maioha," Oriori 70(12-16).
} 
literary criticism and terminology is an act of decolonization: however it is also a concurrent refusal to admit that our Indigenous terms of description were ever fully or successfully colonized in the first place. As Emerence Baker points out: "Our stories, however, focus less on how we are continually disappeared from our own cultural imaginary, and more on the ways that we are giving witness to generations of ongoing cultural "survivance"...". 39 She then goes on to explain the idea of survivance: that not only did Native Americans survive the "genocide of coloniality", but thrived in spite of it. $^{40}$

The title of this thesis is "Calling the Taniwha". This was prompted by the subject matter of a Roma Potiki poem, "The Decision of the Taniwha". ${ }^{41}$ This poem provides a productive structure around which to build my arguments, because it elucidates clearly the issues of naming in Indigenous texts and of who gets to do that naming. So, the 'calling' here is a synonym for naming; however, it is also a calling in that it acts as a karanga, inviting the taniwha into this thesis. As this poem not only inspired my title but also provides the organisational structure of this thesis - from past tense to future tense; from problematics and their implications, to possible repercussions and/or resolutions - it is important that I now reproduce it in its entirety:

\section{The Decision of the Taniwha}

You think people don't know what you do

you think you have fooled them

\footnotetext{
${ }^{39}$ Emerance Baker, “Loving Indianess: Native Women's Storytelling as Survivance," Atlantis 29.2 (2005): 111-122.

${ }^{40}$ Baker 111-122. This statement is equally applicable to Maori.

${ }^{41}$ Potiki, "The Decision of the Taniwha," Shaking the Tree 52-3.
} 
with every smile

every kia ora

every kiss and nod.

You have been twisting and worming for a long time.

I have watched you getting people to agree to things they don't understand, watched you getting a quick yes

when the truth should be a considered no,

put up with your clever bullying

which passes as 'being political'

with those who don't know enough yet -

but the sharp mirror, the stony flint,

the tuatara heart and the decision of the taniwha are coming.

You have been calling all of these through:

the people you scared

the hurt of those wronged

the energy used to contain the fear

the unsettled wairua of those affected by your craft.

All the power that was taken

will come back tenfold,

all the power will come back 
and in the howl of a cleansing wind

and the surge of powerful currents

you will be carried to meet your creation.

Everything you most fear is travelling to you

everything you most fear is travelling

everything you most fear

is here already.

Even though you will want to think murder

it is you who called the taniwha

and you who will have to work for release.

The rest will dance a slow dance

in the light of her scales,

drink enough blood

to gather strength for the real work.

So, is this just another way of looking at the world in nine stanzas? I would suggest not. This text has real practical and applicable meaning, meaning which most clearly emerges when it is viewed in tandem with Mana Wahine Maori scholarship. It is important then to discuss the various meanings and misunderstandings of the word "taniwha" to give both a hint of the ambiguity of the word, and to provide a more general example of how naming and position in relation to a subject are important issues both in Roma Potiki's poetry and in Mana Wahine Maori scholarship generally. 
So, what is understood by the word "taniwha"? In general misunderstanding today, the word "taniwha" has simply come to be a direct translation for "monster". However "taniwha" has significantly more meaning than this. For example, The Reed Dictionary of Modern Maori ${ }^{42}$ translates it variously as "water monster", "ogre" and "powerful person". This last translation gives a hint of the ambiguity of the word. In some of the legends and stories that I grew up with, taniwha do appear as monster-like creatures, big and terrifying. In others, however, taniwha are closer to guardians, protecting areas against those who bring harm. And in most of these occurrences, they are not the creature of mindless destruction that the English word 'monster' brings to mind, but purposeful entities, acting in order to uphold known protocols. I would suggest that whether this makes them 'good' or 'bad' depends on where you are standing.

So then, to call it by its real name, its Maori name, "taniwha", already a range of multiplicities open up and whole different layers of meaning become exposed. Clearly, in the Potiki poem, the taniwha is acting to protect, to defend - to give back to people the power that was taken from them. Who took that power, and who was it taken from? The poem suggests a number of possibilities: it is the colonial governments, taking land and culture from Maori not only by force, but by the stealth that English law and language gave them. It is every New Zealand government since then, that has upheld or ignored the illegality of these actions. It is certain Maori themselves, talking their iwi into quietly accepting what little was left to them:

you think you have fooled them

with every smile

\footnotetext{
${ }^{42}$ P.M. Ryan, The Reed Dictionary of Modern Maori (Auckland: Reed Books - Reed Publishing, 1995) 240.
} 
every kia ora

every kiss and nod. ${ }^{43}$

And I also suggest that it was the power of 'naming', of 'calling' that was taken away, and is now being taken back. By whom? The taniwha in this poem is a very deliberate 'her': therefore I contend that this poem is also talking, perhaps even primarily talking, to Maori women. It was governments, it was men who "called" her, in all senses of that word - who made her come 'here' AND who named her. Now it is the turn of Maori women: to take over, to do the work, to do the naming - the 'calling'. "Everything you most fear is travelling to you". ${ }^{44}$ This thesis operates in the moment between the past and future tenses in "The Decision of the Taniwha". This is a moment of active decolonization, as referred to earlier, because it is taking back a space for Maori, and in particular, for Maori women - the space to talk about ourselves. "All the power that was taken / will come back tenfold": ${ }^{45}$ This thesis aims to provide more of that space, and to take back more of that power. And just as Potiki's poem primarily addresses Maori women, this thesis also places Maori women at its centre and is addressed, in large part, to them. ${ }^{46}$ I now invite Potiki's taniwha into this thesis, to help explore the work ahead.

\footnotetext{
${ }^{43}$ Potiki, "The Decision of the Taniwha" 52-3 (2-5).

${ }^{44}$ Potiki, "The Decision of the Taniwha" 52-3 (36).

${ }^{45}$ Potiki, "The Decision of the Taniwha" 52-3 (30-1).

${ }^{46}$ I will discuss the purpose, and implications, of identifying my 'audience' in this way further in the following chapters.
} 


\section{HAVE WATCHED YOU GETTING PEOPLE / TO AGREE TO THINGS THEY DON'T UNDERSTAND}

This thesis originally began as an investigation into the use of aspects of Maori culture in poetry by Maori women. The intent was to focus on the unique ways in which Roma Potiki, Keri Hulme and J.C. Sturm's poetry fought back against the literary canon's marginalization, and the 'othering' of their culture and gender. Postcolonial and feminist literary theories were to be used to prove that Maori women's poetry deserved a place in that canon. As my research proceeded however, I realized that this position was an inherently negative one: in trying to convince my audience of the worth of this poetry, I was actually engaging in a flag-waving remarginalisation of the texts. It became clear that it wasn't my imaginary reader who lacked understanding of this poetry, and who failed to realise its power and value: it was I who didn't understand that only the weak require defence, and this poetry certainly did not need me to defend it. In order to avoid this trap then it was imperative to begin this thesis with an assumption of the poetry's worth, rather than ending there.

Once I started to write however, problems emerged with my chosen methodologies. I felt that they did not enable me to ask questions of the texts that I was interested in. For example, I wondered what would it look like to read and discuss this poetry from a perspective that not only centred both Maori culture and wahine Maori experiences, but that had originated in Maori culture itself - thus not only truly localizing the discussion, but enabling tino rangatiratanga as well. A methodological framework was required that could consider these factors (and other factors such as Whanau/Hapu/Iwi differences) and be primarily focused on the viewpoints of wahine Maori. Also, and 
most importantly, in attempting to truly centre those viewpoints, the criticism used to guide this thesis needed to have been written not from the perspective of the 'objective' observer ${ }^{47}$, the outsider-looking-in, but from the inside: i.e. by wahine Maori. As Bella Te Aku Graham writes in an article entitled "Postcolonialism, Postmodernism, Postwhatever: Just an/'other' Waka':

...I have noticed that the poststructuralists, postmodernists and postcolonialists tend to clear spaces for me - either on the margin or in some other 'world'. This process of assigning signifiers is, again, not liberation: this is recolonisation! ${ }^{48}$

For these reasons, all of which will be further discussed further in-depth, the body of critical theory often grouped together as Mana Wahine Maori is the most appropriate methodological framework for this thesis.

The central tenet of all Mana Wahine Maori critical theory is that only Maori women can legitimately account for ourselves. In the words of Maori academic Patricia Maringi Johnston, in all other "documentation of our stories, Maori women were written out, marginalized and made invisible."49 This statement is not denying the conclusions about Maori women's stories reached by such approaches as postcolonialism, feminism, postmodernism and so on. However, it does highlight the undeniable gaps in these documentations. This is manifested in Peter Beatson's The Healing Tongue: Themes in Contemporary Maori Literature. ${ }^{50}$ The voice in which

\footnotetext{
47"It galls us that Western researchers and intellectuals can assume to know all that it is possible to know of us, on the basis of their brief encounters with some of us." Linda Tuhiwai Smith, Decolonizing Methodologies: Research and Indigenous Peoples (Dunedin: University of Otago Press; London: Zed Books, 1999) 1.

${ }^{48}$ Bella Te Aku Graham, "Riding Someone Else's Waka: Academic Theory and Tribal Identity," Meridian: the La Trobe University English Review (1995): 60.

${ }^{49}$ Patricia Maringi G Johnston, "Maori women and the politics of theorizing difference," Feminist Thought in Aotearoa/New Zealand: Differences and Connections, eds. Rosemary Du Plessis and Lynne Alice (Auckland: Oxford University Press, 1998): 31.

${ }^{50}$ Peter Beatson, The Healing Tongue: Themes in Contemporary Maori Literature (Palmerston North: Sociology Department Massey University, 1989).
} 
Beatson describes Maori as "organic intellectuals" $" 51$ is certainly directed at a Pakeha audience. And, for the benefit of the Maori reader, he reassures us that he completely understands why Maori writing is (intentionally) not as good art as Pakeha writing:

Maori brains are not to be squandered on the promiscuous satisfaction of intellectual curiosity or used as cultural capital to be converted into personal professional advancement. ${ }^{52}$

Margaret Orbell, in an admittedly outdated statement but one which, as will be seen, is still representative of much academic criticism of Maori writing (if, perhaps, more baldly worded than similar statements made by other critics), stated that: "The purpose [of Maori writing in English] was not originality as such, but the forceful and ingenious statement of recognised truths". ${ }^{53}$ Again, as with Beatson, Orbell's intended audience seems to be a largely Pakeha one.

Such examples of very polite dismissal can also be found in the reviews of Roma Potiki's poetry. These critics tend to highlight a perceived simplicity in her poems: Tom Weston describes Potiki's writing as "both clean and simple." ${ }^{, 4}$ But, (mostly) careful not to offend, these critics explain that the aim of Maori poetry is to communicate and connect with its audience, and thus simple language is necessary: "They declare truths, or at least articles of faith, and their words are tools to that end." ${ }^{, 55}$ Miranda Johnson sums up the attitudes of the almost exclusively Pakeha critics when she asks: "But what is the literary merit of these pieces?"56 As stated at

\footnotetext{
${ }^{51}$ Beatson 44.

${ }^{52}$ Beatson 44.

${ }^{53}$ Margaret Orbell, ed., Contemporary Maori Writing (Wellington: A.H. \& A.W. Reed, 1970) 7.

${ }^{54}$ Weston 10.

${ }^{55}$ Guy Allan, "Poets keeping words sacred," rev. of Stone Rain, by Alistair Campbell, and Rerenga, by Trixie Te Arama Menzies, and Pakake! Pakake!, by Toi Te Rito Maihi, and Stones in Her Mouth, by Roma Potiki, New Zealand Herald 18 July 1992: 2.6.

${ }^{56}$ Johnson 17.
} 
the outset, it is not my aim to 'defend' Potiki's poetry against the ironically simplifying actions of such charges of simplicity. So rather than list the many examples of complexity and multiplicity that exist in Potiki's work, I feel that this is the moment at which to reframe the discussion of Potiki's work with a question: what happens when a Maori woman is placed at the centre of the discussion of both the texts and the criticism - if she becomes the intended audience of both this thesis and Potiki's poetry? I contend that when the approach to poetry written in English by wahine Maori comes from Mana Wahine Maori critical theory, a number of new possibilities open up.

Therefore in order to explain more fully the use and appropriateness of Mana Wahine Maori critical theory in this thesis, I wish to acknowledge and explain its whakapapa. The theoretical concepts of Mana Wahine Maori criticism are connected to Kaupapa Maori scholarship. Kaupapa Maori is a critical methodology that was first used on a large-scale in the education sector in the early $1980 \mathrm{~s}^{57}$. Its aims were to prioritize a Maori paradigm for Maori education; and one of its central tenets was the operation of tino rangatiratanga: a "by Maori, for Maori" approach. ${ }^{58}$ Linda Tuhiwai Smith has been one of the main proponents of Kaupapa Maori research. In her book Decolonizing Methodologies: Research and Indigenous Peoples, she presents a summary of Graham Hingangaroa Smith's definition of the main elements of Kaupapa Maori research. It:

1. is related to 'being Maori'

2. is connected to Maori philosophy and principles

\footnotetext{
${ }^{57}$ However, it must be acknowledged that "[ $\left.\mathrm{t}\right]$ he Kaupapa Maori intellectual endeavour has been part of the academy for decades." Ella Henry and Hone Pene, "Kaupapa Maori: Locating Indigenous Ontology, Epistemology and Methodology in the Academy," Organization 8(2): 234.

${ }^{58}$ Leonie Pihama, Fiona Cram and Sheila Walker, "Creating Methodological Space: A Literature Review of Kaupapa Maori Research," Canadian Journal of Native Education 26.1 (2002): 34.
} 
3. takes for granted the validity and legitimacy of Maori, the importance of Maori language and culture; and

4. is concerned with 'the struggle for autonomy over our own cultural well being, 59

She denies that Kaupapa Maori can be properly described as a paradigm, as it is simultaneously more and less than this:

[Kaupapa Maori] weaves in and out of Maori cultural beliefs and values, Western ways of knowing, Maori histories and experiences under colonialism, Western forms of education, Maori aspirations and socioeconomic needs, and Western economics and global politics ... they are sites of struggle and ... they have some strategic importance for Maori. ${ }^{60}$

Such priorities mean that Kaupapa Maori can clearly be seen as a vital and necessary method of researching topics involving Maori, and that this applies beyond the boundaries of education research. The positive implications of centring Maori concerns in this way, and the important difference this provides from other research and interpretative methodologies - such as those based in postcolonialism and feminism for example - is illustrated by Russell Bishop:

... researchers in Kaupapa Maori contexts are repositioned in such a way as to no longer need to seek to give voice to others, to empower others, to refer to others as subjugated voices, but rather to listen to and participate with those traditionally 'othered' as constructors of meanings of their own experiences". 61

\footnotetext{
${ }^{59}$ Smith, Decolonizing Methodologies 185.

${ }^{60}$ Smith, Decolonizing Methodologies 191

${ }^{61}$ Russell Bishop, "Freeing ourselves from neo-colonial domination in research: An indigenous approach to creating knowledge," Association for Research in Education, Massey University (1995): 17.
} 
Clearly then, this right of Maori to determine the meaning of our own experiences is akin to being in charge of our own decolonization. Roma Potiki's description of Maori theatre is an equally valid observation of her own poetry, and the wider grouping of Mana Wahine Maori Poetry in English: "I see Maori theatre as tino rangatiratanga in action. It is a visible claiming of the right to control and present our own material using self-determined processes which suit us and achieve our political, cultural, and artistic aims." 62 Related to this then is the necessity of determining what further directions Kaupapa Maori might take, or whether there are areas where other methodologies may enable a different kind of discussion.

One of the areas in which some Maori women have argued that Kaupapa Maori has not been employed in a sufficiently rigorous discourse is the area of gender issues. Pihama, Cram and Walker state that "Gender relationships have changed significantly since colonization, and it is argued that Kaupapa Maori needs to engage notions of Mana Wahine Maori in its principles and practice."63 Mana Wahine Maori is more than a guiding principle however: it is a discourse closely related to Kaupapa Maori, and shares many of the same concerns, but it is one in which the needs of Maori women are placed at the centre. To adapt the words of Pihama, Cram and Walker, its main tenet might well be described as being "the affirmation and legitimation of being a Maori [woman]". ${ }^{64}$ A further important difference between them is the institutional location of Kaupapa Maori, emerging as it did from the tertiary sector. As will be shown, discussions surrounding Mana Wahine Maori are much more pluralistic in location, and continue to expand.

\footnotetext{
${ }^{62}$ Roma Potiki, "Confirming Identity and Telling the Stories: A Woman's Perspective on Maori Theatre," Feminist Voices: Women's Studies Texts for Aotearoa/New Zealand, ed. Rosemary Du Plessis (Auckland: Oxford University Press, 1992): 153.

${ }^{63}$ Pihama, Cram and Walker 39.

${ }^{64}$ Pihama, Cram and Walker 39.
} 
Those engaging in the Mana Wahine Maori discourse are Maori women. One of its main progenitors is Ngahuia Te Awekotuku, who began discussing the term, its parameters and possible applications in the mid 1970s. ${ }^{65}$ Irihapeti Ramsden was also a central figure and played a vital role in expanding the parameters of Mana Wahine Maori to include the health sector, and her work ensured that the concept of 'cultural safety' in nursing became a learning requirement for all student nurses. Kathie Irwin too has been hugely significant in the development of Mana Wahine Maori, particularly in its application to the education sector. These three women, illustrated here because of the variety of the locations from which they discuss Mana Wahine Maori, are just an example of the many wahine toa who have been instrumental in the development of Mana Wahine Maori. Though often more implicitly expressed than explicitly so, further critical writing about Mana Wahine Maori has drawn on all of these sources, and continues to do so. To turn now to the original and ongoing development of Mana Wahine Maori, Irwin proposed that the sources of data from which the methodology should develop be fourfold: from Maori society, both present and past; te reo Maori; Maori women's life stories; and tikanga Maori." ${ }^{66}$ She also elucidated exactly why a separate methodology investigating the work of Maori women was necessary: "Mana tane has been protected and nurtured by our culture. Mana wahine has been attacked, rendered invisible in contemporary Maori society and is actively being kept off the record by sectors of the community."67 She argued

\footnotetext{
${ }^{65}$ Ngahuia Te Awekotuku, Mana Wahine Maori: Selected Writings on Maori Women's Art, Culture and Politics (Auckland: New Women's Press, 1991).

${ }^{66}$ Kathie Irwin, "Towards Theories of Maori Feminisms," Feminist Voices: Women's Studies Texts for Aotearoa/New Zealand, ed. Rosemary Du Plessis (Auckland: Oxford University Press, 1992): 6-7.

${ }^{67}$ Kathie Irwin, From Maori Feminism, Te Ao Marama 2 Regaining Aotearoa: Maori Writers Speak Out, ed. Witi Ihimaera (Auckland: Reed Publishing, 1993): 302.
} 
that this is completely inconsistent with traditional tikanga. However, Vapi Kupenga, Rina Rata and Tuki Nepe provide important clarification of this point:

One must be careful, however, not to overstate the position of women. There was a clearly defined reciprocal process in the performance of all activities. While women possessed their own autonomy, it is important to note that: he rereke te mana o te wahine, he rereke te mana o te tane ... the authority/prestige of women is different to that of men. Ko etahi mahi, e kore e taea e te tane, ko etahi mahi, e kore e taea e te wahine ... some tasks are more appropriately performed by men, and similarly some tasks are accomplished by women. ${ }^{68}$

This is related to traditional Maori concepts of 'balance', more of which will be discussed in the following chapter, and which provides the difference between Mana Wahine Maori and 'Maori feminism'. Mana Wahine Maori is not just a proxy translation for "Maori feminism", which would imply that it accepts all of the contentions of traditional feminism and then applies them to Maori society and texts it does not. Linda Tuhiwai Smith defines this difference as "question[ing] the accounts of Maori society provided by men, including Maori men, but which ... argues that the issues of gender for Maori do not make us the same as white women." 69

This difference can also be illustrated in the difference between the terms 'Wahine Toa' and 'Mana Wahine Maori'. The former was a term that started to enter common

\footnotetext{
${ }^{68}$ Vapi Kupenga and Rina Rata and Tuki Nepe, "Whaia te Iti Kahurangi: Maori Women Reclaiming Autonomy," Te Ao Marama 2 Regaining Aotearoa: Maori Writers Speak Out, ed. Witi Ihimaera (Auckland: Reed, 1993): 307.

${ }^{69}$ Smith, Decolonizing Methodologies 188.
} 
usage in the $1980 \mathrm{~s}^{70}$ It was utilised to represent the strength of women, women as warriors $^{71}$, and was much closer to being a translation for 'Maori feminism' than the latter term. However, criticism of the term began to emerge, terming it as a western concept of female power, and noting that there was a more appropriate phrase: Mana Wahine Maori. The most important difference between these two terms is the use of 'mana'.

One sense of the words 'whakamana wahine' is the acknowledgement of the mana of women... This interpretation sits within a contemporary context in which Maori women claim that the natural mana possessed by women has been robbed by ... the way history has been defined and by the impact of social and economic change on Maori women. ${ }^{72}$

So then, Mana Wahine Maori is clearly a more appropriate term as it centres the intrinsic mana of Maori women above the discourse of power that is contained within the use of the word toa.

As has already been seen in this chapter, the word 'mana' emerges over and again as a term of central importance to both Kaupapa Maori and Mana Wahine Maori. Michael Shirres defines personal mana using a tripartite structure:

...mana tangata, power from people, mana whenua, power from the land and mana atua, power from our link with the spiritual powers. ${ }^{73}$

Mason Durie takes this further, and defines mana which includes, as well as extends beyond, the personal:

\footnotetext{
${ }^{70}$ E.g. It was used as the title for an illustrated collection of stories about powerful wahine Maori tupuna, published in 1984, called Wahine Toa: Women of Maori Myth.

${ }^{71}$ Ella Y. Henry, "Rangatira Wahine: Maori Women Managers \& Leadership," thesis, University of Auckland, 1994, 83.

${ }_{72}$ Linda Tuhiwai Smith, Mana Wahine - Mana Maori: A Case Study (Auckland: Maori Education Research and Development Unit University of Auckland, 1990): 17

${ }^{73}$ Michael P Shirres, Te Tangata: The Human Person, (Auckland: Accent Publications: 1997): 53.
} 
1. Mana Maori

2. Mana Atua

3. Mana Tupuna

4. Mana Tangata

5. Mana Whenua

6. Mana Moana

7. Mana Tiriti

8. Mana Motuhake ${ }^{74}$

In order to fully cement the importance of 'Mana' to 'Mana Wahine Maori', I will now investigate its literary implications in relation to Roma Potiki's work, using certain elements of Durie's definitions as my structure.

\section{MANA TANGATA:}

"All of us come into being as chiefs". ${ }^{75}$ This solitary line in the poem "Crowned" emphasizes the importance of Mana Tangata, as something not conferred by others, but initially inherent in everyone. "And you and I / a kind of proof of existence". 76 The "you and I" here is important, and serves as an example of the difficulties of relying on straight dictionary translations of crucial Maori concepts. Mana Tangata is not about the mana of $a$ person, or the mana of a group of people. It is the mana to be found in people, as they relate to each other. As Michael Shirres explains it, "To be a

\footnotetext{
${ }^{74}$ Mason Durie, Te Mana, Te Kawanatanga: The Politics of Maori Self-Determination, (Auckland: Oxford University Press, 1998): 1. This list is an edited version of Durie's contents page.

${ }^{75}$ Potiki, "Crowned," Oriori 11(18).

${ }^{76}$ Potiki, "Crowned," Oriori 11 (5-6).
} 
person is not to stand alone, but to be one with one's people, and the deeper the oneness the more we are truly persons and have that mana tangata". ${ }^{77}$

\section{MANA WHENUA}

$$
\begin{aligned}
& \text { I am Papatuanuku } \\
& \text { giving completely I hold strength in its upright } \\
& \text { form }-{ }^{78}
\end{aligned}
$$

The poem is typographically centred, emphasizing the absolute centrality of the land in Maori culture: Mana Whenua. Here, Mana Whenua is acting as the poem's poutokomanawa - life-giving, as Hineahuone was originally formed from the land and life-sustaining: "you who press on my skin / tread the body you do not recognize". ${ }^{79}$ As illustrated earlier in this chapter, most critical interpretations of Mana Wahine Maori poetry, while acknowledging the poet as a Maori woman, do not tend to delve very deeply into the implications of this for reading the poetry. The clinical "press" of academic fingers, while investigating the 'body' of work that the grouping Mana Wahine Maori poetry in English might suggest, nevertheless often fail to understand its deeper nature - never going more than skin-deep. For instance, Miranda Johnson interprets Potiki's poetry as offering "a return to the natural world" as a balm for those alienated from the land by the concrete boxes that are their homes and workplaces. ${ }^{80}$ This seems a quite eurocentric explanation for poems such as "Papatuanuku", which may also (and more appropriately?) be read to celebrate a current and ongoing connection with Mana Whenua in everyday Maori culture and

\footnotetext{
${ }^{77}$ Shirres 53.

${ }^{78}$ Potiki, "Papatuanuku," Shaking the Tree 26(1-3).

${ }^{79}$ Potiki, "Papatuanuku," Shaking the Tree 26(8-9).

${ }^{80}$ Johnson 17.
} 
life, rather than offering a 'retreat' from the 'real' world. "I need no definition":." while this may be taken to mean that the poetry is beyond definition, the succeeding, and final, line "I am Papatuanuku, the land" will provide its own meanings. The essential link between Maori and the land is made even more explicit in the following lines: "The body and the land are one. There is no separation. / Te whenua ki te whenua." ${ }^{83}$ Any syntactical differencing between those two literal sustainers of human life, the placenta and the land, would be an exercise in artificiality: it is all, literally, whenua. In an interview with Briar Woods, Roma Potiki points out that it is not only Pakeha who fail treat Papatuanuku with the respect that she deserves: "I remember Eva Rickard saying that often men in their whaikorero would make reference once to Papatuanuku when they open their speech, and that it was not enough. In actual fact we're treading on her, she's a provider of all these things... ${ }^{\prime 84}$ This reminder of the need to take active part in preserving Mana Whenua not only physically, but verbally, emphasizes the crucial syntactical discussions that Mana Wahine Maori poetry in English enables. Regardless of wars fought for land and tribal boundaries, ultimately Papatuanuku 'belongs' to all Maori, as we are all a part of her. The unsuitability of this English word 'belong', with its emphasis on formal ownership and contracts for land is emphasized by the line in Roma Potiki's poem "Nga Tamariki A Tane": "There can be no trespass here". ${ }^{85}$ This theme is presented more stridently in her poem "Play Money". The sale of land, or, in this case, the acceptance of a financial payout in return for ceasing to pursue the return of land, via the 'fiscal envelope' is wrong, a betrayal: "In the end Maori will be left to answer

\footnotetext{
${ }^{81}$ Potiki, "Papatuanuku," Shaking the Tree 26(12).

${ }^{82}$ Potiki, "Papatuanuku," Shaking the Tree 26(13).

${ }^{83}$ Potiki, "Te Whenua ki te Whenua," Oriori 62(13-14).

${ }^{84}$ Briar Wood, "I need no definition," int. with Roma Potiki, Hecate 21.1 (May 1995): 58-6.

${ }^{85}$ Potiki, "Nga Tamariki A Tane," Oriori, 86 (6).
} 
/ why we abandoned Papatuanuku / our living mother". ${ }^{86}$ Clearly, Mana Whenua is not just a principle, or an ideal, but integral factor in our lives.

\section{MANA ATUA}

Tane listens to the messages passing between

the turn of sunset and moonrise,

listens as a father

to the growing season of our needs. ${ }^{87}$

The naming of Tane as "father" in this poem "Te Hurihanganui" expresses the immediate significance of atua for Maori: not as distant 'deities', but as family. Michael Shirres relates Mana Atua to Mana Whenua: "So for many Maori their ancestral land cannot be bought or sold. We cannot buy or sell our own mother." ${ }^{88} \mathrm{He}$ goes on to express why, for us, this involves mana: "One with the people, one with the land, we also become one with the atua, the spiritual powers. They, the spiritual powers, are our immediate source of mana. They are the source of our tapu." ${ }^{89}$ The common reference to Tane as father goes beyond the metaphorical Christian reference to God as "our father": as creator and subsequent partner of the first woman Hineahuone, as well as other women including his daughter by her, Hinetitama, Tane may be referred to as our actual and ultimate father ${ }^{90}$. His action of separating his

\footnotetext{
${ }^{86}$ Roma Potiki, "Play Money," The Angus Inn Pub Poets III, ed. Moira Wairama, (Petone: Hutt Valley Community Arts Council, 1995) 59-60: 60(19-21).

${ }^{87}$ Potiki, “Te Hurihanganui," Oriori 22(12-15).

${ }^{88}$ Shirres 55.

${ }^{89}$ Shirres 57.

${ }^{90}$ In the explanatory appendix to Oriori, Potiki writes: "Every newborn baby of Maori descent is a child of Tāne. Even if we don't know the whakapapa (geneology) in between, we can still claim Tāne as our tipuna (ancestor)." Potiki, Oriori 93.
} 
parents so that all life could grow also supports such a statement. The Mana Atua expressed here is of an immediate, essential presence. He does not fit the academic description of "deity", as something to worship at a far off remove, "The pulsing cord of our histories draws you even closer," 91 but is related by whakapapa to all Maori.

\section{MANA TUPUNA}

“... My ancestors were so fierce; / so female and so male and so themselves as to be other. I think of them as / living vessels. We are together." ${ }^{\text {, }}$ Read with many of the critical reviews of Potiki's poetry, this positioning of one's ancestors as contemporaries sounds either romantic and/or simplistic. ${ }^{93}$ Both interpretations however ignore the importance of the word "living" in the poem: that is, that our tupuna live, not as memories, but as formative, influential beings (in every sense of that word: be-ings, to be, to exist). This is supported toward the end of the poem with the entreaty to Hineteiwaiwa to "protect our living whakapapa". ${ }^{94}$

I plummet through the days

a bird that feels no rain

only salt heat

from the wide basins

joined by bone

in head and hip. ${ }^{95}$

\footnotetext{
${ }^{91}$ Potiki, "Te Hurihanganui”, 22(4).

${ }^{92}$ Potiki, "A Careful Turmoil,” Oriori 14(8-10).

${ }^{93}$ And 'romantic' and 'simplistic' are both descriptors which we have seen applied to Potiki's poetry by critics.

${ }_{94}^{94}$ Potiki, "A Careful Turmoil," 14(18).

${ }^{95}$ Potiki, "Plumme,t" Shaking the Tree 19(1-6).
} 
This poem lends support to the assertion that there will be a cultural and critical imbalance if Mana Tupuna is not acknowledged: there will be dry without hope of wet, and salt will leach all liquid from the ground, ensuring no crops - or hope - will ever be able to grow through. The wide bone basin joining hip to hip, the pelvis, is where the rangatahi will emerge. Iwi: the bone people, whilst the wide bone basins of the head are where the memory of the iwi is contained. However, without the flesh, the feeling, these are dry, dead wastelands, containing only memory, and not action. To complete Potiki's analogy, theory without the lived actuality provides no parachute to slow the downward journey through the days of life.

I must press

the old ones close

before I am done. ${ }^{96}$

No thing - person or critical methodology - can claim completeness without reference to and acknowledgement of the ancestors and ancestral knowledge. The difficulty and effort required to do so is illustrated by the physical separation of stanza two from stanza three: the words "press" from the former and "close" from the latter reach toward each other across the white emptiness of the page. The possibility of success is hinted at by the lowercase "the" of the third stanza, easing the journey.

Crazy wind and stinging sand

let me exhaust it all

till I feel something warm on my face

other than the burn of tears. ${ }^{97}$

\footnotetext{
${ }^{96}$ Potiki, "Plummet," 19(11-13).

${ }^{97}$ Potiki, "Plummet," 19(14-17).
} 


\section{MANA MOTUHAKE}

Finally, acknowledgement of Mana Tangata, Mana Whenua, Mana Atua, Mana Tupuna and all the other manifestations of mana is clear evidence of Mana Motuhake in action. In the concluding sentence of her book Maori Sovereignty, Donna Awatere wrote: "This is the right we reclaim in reinforcing the separate reality of our tipuna and making it our own. To do this is to take the first step toward Maori sovereignty." 98 Roma Potiki has also explicitly stated her intention to enact tino rangatiratanga in her creative work:

The driving force of Maori theatre of today is ... to re-assert the mana of the tangata whenua. I see Maori theatre as tino rangatiratanga in action. It is a visible claiming of the right to control and present our own material using selfdetermined processes which suit us and achieve our political, cultural, and artistic aims. Any theatre that upholds the mana of tino rangatiratanga is Maori theatre. $^{99}$

Clearly such a statement as this is just as applicable to Potiki's own poetry, and so I now offer a close and sustained reading of one of those poems: "A Cloak and Taiaha Journey" 100 both as an example of "tino rangatiratanga in action", and as an illustration of the efficacy and importance of the 'Mana' in this grouping I have named Mana Wahine Maori Poetry in English. ${ }^{101}$

\footnotetext{
${ }^{98}$ Donna Awatere, Maori Sovereignty, (Auckland: Broadsheet, 1984): 107.

${ }^{99}$ Potiki, "Confirming Identity and Telling the Stories," 153.

${ }^{100}$ Potiki, "A Cloak and Taiaha Journey," Shaking the Tree 10.

${ }^{101}$ In contrast to my assertion here that this poem enacts 'Mana', I feel that it is interesting to add

David Eggleton's opinion of the poem "A Cloak and Taiaha Journey":

...poems about her direct experiences with traditional Maori culture sometimes wobble uneasily between sophistication and faux-naivety as viewpoints collide: the way she communes with her ancestors, the "old ones" at Cape Reinga stops just this side of spiritualism and telepathy - the rhetoric doesn't quite ring true.

David Eggleton, "Poems from the inside out," rev. of Shaking the Tree, by Roma Potiki, Evening Post (22 May 1998): 5.
} 
The main theme of the poem "A Cloak and Taiaha Journey" is centred on ideas of communication: indeed, that single word is the poem's final line. These conversations do not take place with words however; rather: "shapes sing"; "[t]hey do not speak in the language of sound"; they are "speechless" and must resort to "stamping out messages". One of the routes to communication used in the poem is via words; in particular, the names given to things. In the first stanza, the speaker is "on the way to the Cape." Taken literally, she could be going to the East Cape, the North Cape, Cape Nicholson, Cape Kidnappers, or one of the myriad other 'Capes' that the early European explorers gave as new names to geographical locations. However, Maori also laid down Capes on the landscape. An example of this is the town of Taupo, which is more properly known as Taupo-nui-a-Tia. This means 'the great cloak of Tia', a cloak that the explorer Tia threw down from his shoulders and which became the lake. Taken figuratively though, the speaker's Cape also suggests the "cloak and taiaha journey" of the title. As a symbol it hints at furtiveness, invisibility, and hiding: the English word here acts as a cover to determining real meaning. The replacement of the expected word 'dagger' with 'taiaha' is also important. This use of the Maori does more than situate the poem within a local frame of reference; this naming is an extension of the communication referred to earlier, and carries the suggestion of a challenge. But to whom?

It is likely that the poem is challenging both poet and reader to engage not only with Maori language, but with Maori culture. This is illustrated by the imagery used to describe the body through the course of the poem. It begins with the "skinny arms and bodies/of old ones", but a few lines later it emerges that these bodies are "unearthly". In the next stanza however they become more natural, their limbs absorbed in 
repeating the ridges and peaks of the land. This movement from unnatural to natural, from unearthly to ground in the earth is echoed by the movement in the language. The active verbs relax from the stiffer "etched", "chiselled" and "carve" into "dance" and "breathing". The "old ones" become "tupuna", the "dry land" is refreshed by the "waves". Ironically, it is the Latin word "creosote" in the sixth stanza that solves the mystery of theses bodies. A wood preservative? The words etch, chisel and carve suddenly come into new focus - the tupuna are whakaairo, lining the walls of the wharenui. And though the Latin solved this mystery, it cannot help with the poem's deeper silences.

A carving is a three-dimensional picture dug from wood, stone or bone. If the word "whakairo" is used instead, different images are suggested and remembered. One of the origins of whakairo springs to mind: the pakiwaitara of Rua-te-pupuke and his fight with Tangaroa. Because the whakairo in Tangaroa's wharenui could speak, Ruate-pupuke covered the windows so they wouldn't wake up with the dawn. This allowed him to surprise Tangaroa, kill his whanau and drag the wharenui and its tekoteko, his son, above the waves and back onto dry land. In the poem then, the "pattern of breathing" the speaker notices from the "old ones" seems ominous and may explain the stones "you'd feel on the back of your neck/ before you fell". And as with the pakiwaitara, "[t]hey are here in waves". However, here a Latin name, prosopopeia, solves no mysteries. The whakairo are neither the personification of anger, nor of language or culture. They are the tupuna, "the women and men, the others". To ignore them and what their presence means would be the real danger. In the second stanza of the poem, the reader is reminded that the "old ones" hold the "tatau of land, / sky and water". If the reader cannot understand the language of the 
whakaairo, then they cannot understand the land, sea, sky or their whakapapa contained therein. In this case, the "stones in their hands", the taiaha of the tupuna, become uselessly, permanently, fixed to the wall. Only when they are understood do their pakiwaitara become real. Just as Maori had the use of creosote before they had the Latin name for it, so Maori culture and language work together in this poem to expose more of its complexities and leap out into its infinities. The "airless dive" feared in the first stanza may well be a reading of this poem that ignores these deeply embedded Maori elements.

Finally, it is not only language and culture that the poem challenges the reader to engage with, but Potiki's poetry as a whole. The symbol of the journey also emerges here. The poem may be read as a metaphor for the unexpressed intent - the secret, cloak-and-dagger journey - of not only this book, but Potiki's whole collection. The title of her first volume of poetry is Stones in her Mouth. While her poetry has always issued challenges, the stones are in her fist this time. These poems are not only weapons however, but messages: "seeds". Something is being planted and is rising to the surface. This is the "oil on the tongue", the oil is loosening the tongue - there are no longer stones in their mouths - now they can speak, and the words rolling off of their/our tongues are seeds of a new understanding. 


\section{PUT UP WITH YOUR CLEVER BULLYING / WHICH PASSES AS 'BEING POLITICAL'}

It is interesting that much criticism surrounding Mana Wahine Maori writing - both critical and creative - bandy the word 'political' around so often. I will join with Roma Potiki in deriding the misappropriation of this word to describe any situation in which a strong opinion is expressed, and, like her, reclaim it for its true transforming potential. I agree with Haunani-Kay Trask's assertion that "culture is political". ${ }^{102}$ Before proceeding down that road however, I think that it will be valuable to examine some of the critical reviews of Potiki's work, and they ways in which critics have variously approached what they all seem to term the 'political' aspects of her poetry. I will show that the general discomfort with and dismissal of (by largely ignoring the poems' contents and the implications of their own use of 'political') the deeper meaning of these poems consigns the poet/ry to one of two unsatisfactory boxes: either that of 'victim' or 'angry woman'. In the 'angry woman' camp, Miranda Johnson provides some perplexing observations. Firstly, she teases Elizabeth Caffin for a refusal to evaluate the worth of Potiki's "political poems... angry as they are," then following this dismissal of such a simplistic catch-all phrase, she herself then reinscribes the 'angry woman' thesis: Shaking the Tree "...is not so overtly and predominantly political. That is not to say it is less angry." ${ }^{104}$ Guy Allan refers to her "political poems" as "building rolls of invective" 105 while Aroha Harris says of the poems in Stones in Her Mouth: "They create an impression of the ominous accusing

\footnotetext{
${ }^{102}$ Haunani-Kay Trask, "Writing in Captivity: Poetry in a Time of De-Colonization," Navigating Islands and Continents: Conversations and Contestations in and around the Pacific, eds. Cynthia Franklin, Ruth Hsu and Suzanne Kosanke (Honolulu: College of Languages, Linguistics and Literature, University of Hawai'i and the East-West Center, 2000) 52.

${ }^{103}$ Johnson 17.

104 Johnson 17.

105 Allan 6.
} 
finger, or one hand on hip, one holding loud-hailer."106 The problem here is not essentially with the connection of 'angry woman' to 'political' by the critics, as some of Potiki's poems do indeed have an irate voice, and she also refers to herself as 'political' on the backcover blurb of Stones in Her Mouth. The problem is that the range of experiences that the word political could cover are large and various, but never defined by her critics, and the 'angry woman' is a caricature that refuses to admit the serious intent behind Potiki's writing. ${ }^{107}$ So what does Roma Potiki mean when she describes herself as political? "That Maori Girl” seems to offer an opinion:

That Maori girl's a radical

all that stuff about the Treaty

saying land should go back to them,

that whites are tryin' to kill her.

Other Maoris don't think like that. ${ }^{108}$

The political element here is not so much that of the position of the "radical" although some of her other poems do discuss the Tiriti and land rights ${ }^{109}$ - but that she has made explicit what "Other Maoris" may think, but don't verbalise. This is where the grouping Mana Wahine Maori poetry in English enables us to point out that, according to their poetry, actually most "Other Maoris", and certainly, wahine Maori poets, do indeed think like "that".

As mentioned in the preceding chapter, the kaupapa of Mana Wahine Maori provides the most appropriate framework not only for this thesis but, I will argue, also for any

\footnotetext{
${ }^{106}$ Aroha Harris, "Poems challenge," rev. of Stones in Her Mouth, by Roma Potiki, Evening Post (14 Aug 1992): 5.

107 David Eggleton's article however did go into detail to explain what it was that he saw as the 'political' aspects of her poetry. Eggleton 5.

${ }^{108}$ Potiki, "That Maori Girl," Stones in Her Mouth, 11(6-10).

${ }^{109}$ Eg. "Change is necessary": "150 years of repression / 150 years of losin' more each year". Potiki, "Change is necessary," Stones in Her Mouth, 34(46-7).
} 
research pertaining to, and performed by, Maori women. Having previously outlined the whakapapa of this critical theory, I now turn more fully to the reasons behind its development. There were and still are a number of reasons for the development of a critical methodology indigenous to Maori women. Before beginning however, it is necessary to acknowledge the self-conscious effort that many of the women whose work I draw on have made to avoid writing from a position of disadvantage. By disadvantage, I mean writing from a marginal position as victim of external and internal oppression. ${ }^{110}$ In light of this, and for reasons which will be expanded upon further within the course of this chapter, I will be self-conscious in avoiding focusing on the disadvantages Maori women have and still do suffer, unless to more fully clarify historical injustices.

As has already been stated, 'Maori feminism' is not an appropriate translation for Mana Wahine Maori, for a number of reasons. In their article examining the causes of the marginalization of Maori women both in society and by academics, Leonie Pihama and Patricia Johnston explain that the problem with such a limited translation of the idea of Maori feminism is that: "Difference is defined for Maori [by Pakeha], not in terms of unequal power-relations, or unequal social, economic and political positions, but in terms for Maori which emphasise only language and culture." ${ }^{111}$ In all practical usage, this "turns difference into exclusion". ${ }^{112}$ The term that Pihama and Johnston, as well as many other Maori women academics, use is "intersection": a point at which gender and race meet. ${ }^{113}$ Kathie Irwin states that the only practical way

\footnotetext{
${ }^{110}$ As elucidated by Johnston, "Postcoloniality, Idenity and the Politics of Location," Feminist Thought in Aotearoa/New Zealand, 36.

${ }^{111}$ Leonie Pihama and Patricia Johnston, "The marginalization of Maori women," Hecate 20.2 (Oct. 1994): 83-98.

${ }^{112}$ Pihama and Johnston 83-98.

${ }^{113}$ Pihama and Johnston 83-98.
} 
to fully and complexly represent this intersection, is to develop a feminist theory in which Maori cultural and social paradigms are placed at the centre of the discourse. ${ }^{114}$ Without an Indigenous theory, she says, “... we come to understand ourselves only as others see us." 115 As illustrated in the previous chapter, it seems that Mana Wahine Maori has become that theory. ${ }^{116}$ In elucidating their reasoning behind the need for such a theory, Pihama and Johnston use the pertinent example of colonial governments placing English-language-using schools in Maori-majority/only communities. They point out that the colonial governments' aim was to assimilate Maori by getting Pakeha teachers to model to these communities, standards of “appropriate behaviour". ${ }^{117}$ Here I argue that mainstream 'Pakeha feminism' is open to being accused of trying to model similar behaviour.

When a critical theory specifically pertaining to concerns of Maori women first began to be mooted in critical articles and conference papers, one of the main concerns was the sources from which it should develop. Kathie Irwin listed four main sources: from "Maori society, both te ao hou and te ao tawhito (the present and the past); te reo Maori, the Maori language; Maori women's herstories, the stories of the lives of our women; and nga tikanga Maori, Maori customary practices." ${ }^{118}$ As will be illustrated in this chapter, Mana Wahine Maori has indeed developed from these sources, amongst others. Besides issues of source, the other major question broached was of who should perform readings using the theory. Here, as with source, a large amount of

\footnotetext{
${ }^{114}$ Irwin, "Towards Theories of Maori Feminisms," 2.

115 Irwin, "Towards Theories of Maori Feminisms," 4.

116 Although many Maori women academics don't specifically name "Mana Wahine Maori" when discussing the existence of Indigenous critical theories, I will argue that the similarities between the parameters they describe and those that Mana Wahine Maori have are shared to the extent that to state that this is in fact the location at which they are working would not be an outlandish claim.

${ }^{117}$ Pihama and Johnston 83-98.

${ }^{118}$ Irwin, "Towards Theories of Maori Feminisms," 6.
} 
agreement can be seen amongst those writing in this area. Clearly, Maori women should be the ones to develop and use such a methodology: "participation is central to empowerment". ${ }^{119}$ Further to this, Irwin stresses the difference that Maori women's analyses of other Maori women (both traditional and contemporary) have from those of, particularly, “... Pakeha male anthropologists and the Pakeha women whose reconstructionist work is based on theirs." 120 The poem "death is too high a price to pay for your approval" critiques the methodology and potentially destructive information-gathering techniques of the latter:
the answers that will satisfy yr need
for what
you see as knowledge
and I grow sick and less than myself
in the giving
in the trying to satiate you. ${ }^{121}$

$\mathrm{i}$ bend and thrash, trying to draw out of myself

"For what you see as knowledge" - clearly, there are different kinds of knowledge, and the type provided by the early 'scientific' Pakeha ethnography was only one of these. ${ }^{122}$ If the ethnographic knowledge is to be counted as the only real 'evidence' about early Maori society, the result is a two-dimensional Maori so much "less than myself", who only exists on paper. To extrapolate, this is not to say that only Maori

\footnotetext{
${ }^{119}$ Irwin, "Towards Theories of Maori Feminisms," 7.

${ }^{120}$ Irwin, "Towards Theories of Maori Feminisms," 7.

${ }^{121}$ Potiki, "death is too high a price to pay for your approval," Stones in Her Mouth 60(4-10).

${ }^{122}$ Although this particular type of 'knowledge' will be interrogated further later on in this chapter, I have decided not to list or examination all of the multiple ways in which this 'knowledge' has disadvantaged Maori women. This decision is in line with my earlier assertion that I will not be performing a negativist reading of Maori women that reinscribes us as victims, as I do not believe that that is a productive position to pursue within the parameters of this project.
} 
women have the right to interrogate literary works written by other Maori women rather, that only Maori women can safely ${ }^{123}$ attempt to explain the Maori aspects of those texts. Undoubtedly, other analyses $\operatorname{can}^{124}$ be made of the text: for example, a feminist analysis by a Pakeha female, which would probably include comment on the text's Maori elements. What should be made explicit though is that she is exploring her interpretation of the text as a Pakeha.

We Maori women also need to take care in our own use of Mana Wahine Maori when reading texts by other Maori women. One specific area in which special care is appropriate is in the area of Iwi/Hapu/Whanau differences. For example, "Iwi Maori have suffered different fates at the hands of colonizers... this area is one in which tribal kawa and tikanga differ markedly."125 For example, a poem that refers to an ancestor who is not widely known in general Maori society may be interpreted as a 'recovery project', bringing to light little-heard-of stories. However, if it emerges that the poet and the ancestor belonged to the same hapu, that same poem might also be read as a celebration of a well-known tale. One of these interpretations is an argument for inclusion; the other, a statement of centrality - these enable quite different discussions to be made of the same text. This particular area will be explored more fully in chapter four, in a discussion based on the multiplicities of Mana Wahine Maori methodologies.

\footnotetext{
123 "Kaupapa Maori is research which is culturally safe, which involves the mentorship of elders, is culturally relevant and appropriate while satisfying the rigour of research, and which is undertaken by a Maori researcher, not a researcher who happens to be Maori": Kathie Irwin, "Maori Research Methods and Practices," Sites 28 (Autumn 1994): 27. For further definition of this type of usage of the word 'safety', I refer to Irihapeti Ramsden's PhD thesis on the subject of cultural safety: Cultural Safety and Nursing Education in Aotearoa and Te Waipounamu.

${ }_{124}$ And should be made: obviously, the more critical attention paid to poetry by Maori women the better. As the mantra says, "all publicity is good publicity."

${ }^{125}$ Irwin, "Towards Theories of Maori Feminisms," 6.
} 
One of the main problems that the use of Mana Wahine Maori to read texts seeks to address is the issue of 'balance' in Maori society: that is, an acknowledgement of its vital importance in traditional society, and an attempt to restore that balance, which arguably no longer exists in contemporary society. This is neatly encapsulated in Roma Potiki's poem "Bound To". ${ }^{126}$ The aim of Mana Wahine Maori and its crucial difference from eurocentric cultural and radical feminism ${ }^{127}$ is that its aim is not to overthrow male power, but to seek a return to the balance that existed pre-colonialism, when Maori women shared equal power with Maori men. 128 "bound together in the darkness / our faces push out of the night": ${ }^{129}$ Ranginui and Papatuanuku both emerged out of Te Kore. Ranginui and Papatuanuku were originally locked together, entwined around each other. These lines also refer to the sexual acts between human men and women, and which could be seen by an unknowing outsider as an act of aggression, rather than of sexuality. "man and woman struggle with each other / sigh and breathe as one wrist locks another." ${ }^{130}$ Clearly though, such an interpretation would be misinformed: "no one is crying / we both smile."131 The two participants are in full control of themselves and their actions - there are no victims here. This poem, and the act of sexual union described therein, may act as a direct analogy for the balance of power that existed between men and women in traditional Maori society. "one thigh rolls / the other slumps."132 The activities of each are different, but

\footnotetext{
${ }^{126}$ Potiki, "Bound To," Stones in Her Mouth, 54.

${ }^{127}$ I refer here to Ella Henry's definitions of cultural feminism and radical feminism in her thesis: Henry, Rangatira Wahine 18.

${ }_{128}$ This 'equality' will be examined in detail further on in this chapter, however, Chapter Five acknowledges that this was not the case for all (or even most?) Maori iwi. The claim I make here is one found in many examples of Mana Wahine Maori critical writing, such as Ani Mikaere's thesis: Ani Mikaere, The Balance Destroyed: Consequences for Maori Women of the Colonisation of Tikanga Maori, thesis, Waikato University, 1995 (Auckland: The Institute for Maori and Indigenous Education and Ani Mikaere, 2003).

${ }^{129}$ Potiki, "Bound To," Stones in Her Mouth, 54(1-2).

130 Potiki, "Bound To," 54(3-4).

131 Potiki, "Bound To," 54(15-16).

132 Potiki, "Bound To," 54(12-13).
} 
complementary, both working toward the same goal. Potiki herself states that her work (in this example, with her theatre group) is an acknowledgement of such complementarity: "We are trying to look beyond gender issues. I don't believe that the women in our group are secondary to the men. We make demands on the men, but in turn we respect them... Everyone brings their own mana to the work." ${ }^{133}$ Ella Henry, in her thesis on Maori women managers, also refers to a balanced relationship between men and women. Her focus is on traditional Maori society, as exemplified in the relationship between atua:

... traditional Maori society was underpinned by a cosmology that emphasized and reinforced the dialectical parallelism of female-male complementarity, as personified by Papatuanuku - the earth mother, and Ranginuiatane - the sky father. This complementarity was exemplified in daily practice by the unique leadership roles which women fulfilled in traditional Maori society. ${ }^{134}$

In "A Careful Turmoil”, Roma Potiki emphasizes that this balance has always existed: “...My ancestors were so fierce; / so female and so male and so themselves as to be other. I think of them as / living vessels. We are together.",135

Her statement regarding her theatre group can thus be seen as a continuation of such a tradition.

Another illustration of togetherness is seen in the lack of gendered pronouns in the Maori language. ${ }^{136}$ If there is no "he" or no "she" then they are literally, lexographically "other". Ani Mikaere questions how a culture that does not distinguish linguistically between the sexes can be described as institutionally

\footnotetext{
${ }^{133}$ Roma Potiki, "He Wahine Kaimahi Whakangahau," Race, Gender \& Class 9-10 (Dec. 1989): 117.

${ }^{134}$ Henry iii.

${ }^{135}$ Potiki, "A Careful Turmoil," Oriori 14(8-10).

${ }^{136}$ I refer here to Mikaere 8: both the personal pronouns (ia) and the possessive personal pronouns (taana/toona) applied equally to both sexes.
} 
sexist. $^{137}$ Linda Tuhiwai Smith also supports this point and argues that such an example goes beyond issues of language to the heart of Maori cultural values. ${ }^{138}$ Before examining specific examples of balance between the sexes in traditional Maori society, it is necessary to explain why it was seen as such a vital principle. Ani Mikaere, in her thesis on the implications of the destruction of this balance for contemporary Maori society, refers to Rose Pere's explanation that the wellbeing of an entire community and their mauri, relied on the maintenance of distinct but complementary roles for men and women. ${ }^{139}$ Linda Tuhiwai Smith proposes that it was even more important than this: "In order for society to survive the balance in roles needed to be maintained. Colonisation upset this balance by promoting the activities and perspectives of knowledge held by Maori men at the expense of Maori women." ${ }^{\prime 40}$ To look at a specific example of this balance then, this can be seen in the power of women in traditional Maori society which, it will be argued, was the equal of male power. In "Shaken"141, Roma Potiki presents a description of a woman during labour in traditionally male terminology:

The birth stance,

a haka of flexible dimension,

the posture of a woman entering an extending circle.

A stomping, sure-footed woman,
growing daily
into the season of her own power.

\footnotetext{
${ }^{137}$ Mikaere 8

${ }^{138}$ Linda Tuhiwai Smith, "In search of a language and a shareable imaginative world: e kore taku moe e riro i a koe," Feminist Thought in Aotearoa/New Zealand: Differences and Connections, eds. Rosemary Du Plessis and Lynne Alice (Auckland: Oxford University Press, 1998) 98.

${ }^{139}$ Mikaere 63.

${ }^{140}$ My emphasis. Smith, Mana Wahine - Mana Maori 17.

${ }^{141}$ Potiki, "Shaken," Oriori, 30.
} 
The woman in this poem is performing her own type of haka in giving/preparing to give birth: she stands, legs apart, knees bent, with her hands on her thighs, but it is a uniquely and solely female haka. She is undoubtedly powerful, but in an entirely different way to the men who perform their own haka: both, however, call on tupuna to assist in the separate challenges that each is about to face, or offer. This is just one example at the root of the conception of 'balance' in traditional Maori society. Ani Mikaere illustrates the extent and whakapapa of this power:

The female presence at the beginning of the world is therefore allencompassing. The female reproductive organs provide the framework within which the world comes into being. Moreover, the blueprint for the creation of human life is set out in this story. It establishes a cycle that is repeated with each and every human birth, a cycle within which the female role remains forever central. ${ }^{142}$

This traditional power remains a contemporary power of Maori women. In "for my daughter: Te Whaea", Potiki writes of "an ancestor / returned to me in birth / this newborn." ${ }^{143}$ It is not just the ancestor who returns, but the ancestral power that is put on with the act of re/birth. Ella Henry asserts that those would say that this is an example of women who were only powerful "behind the scenes" are subscribing to western conceptions of power:

The implicit assumption here, however, is that 'behind the scenes' is less significant than 'in-front' of the scenes. But, ideas about 'behind' and in-front', are saturated with Western values associated with public and private spheres of activity. If Maori women were powerful 'behind the scenes', it may well be that 'behind the scenes' was a meaningful locus of political activity and control,

\footnotetext{
${ }^{142}$ Mikaere 17.

${ }^{143}$ Potiki, "For My daughter: Te Whaea," Stones in Her Mouth 39(1-3)..
} 
given there is no evidence that the public and the private were assigned the same meanings in traditional Maori society, as they are in Western society. ${ }^{144}$ This is also an example of the power in traditional Maori society that was not only practiced by, but was based in and originated with Maori women.

In addition to conceptions and examples of power, there is a large amount of knowledge that traditionally originated from Maori women too. In her investigation of Maori women leaders, Rangatira Wahine, Ella Henry relates that the kuia Rose Pere was instructed in the Whare Wananga of ancient Hawaiki by Tuhoe Potiki, Kahungunu and Ruapani elders, which is a claim that Pakeha-originated Maori ethnography denies as impossible. ${ }^{145}$ It illustrates that there are, and always have been, female equivalencies to male power in Maori society. However, what is most significant about Henry's claim is that it is a passing-on of traditional knowledge about Maori society, told orally to her by a kuia, which actively favours a Maori conception of knowledge above that which may be quoted by reference to a page number in a Pakeha account of 'historical' Maori ethnography. These are all examples of traditional Mana Wahine Maori in action, which illustrates both the whakapapa for our contemporary usage of the term and the potential remaining to be explored with it.

Although I acknowledge that there are many deep-seated problems with both traditional and contemporary Pakeha definitions of Maori knowledge, such as that inscribed in the 'canonical' texts of historical Pakeha-written Maori ethnography (like those texts written by Best, Grey, White et. al), I will not be engaging with either their definitions or their problematics in this thesis. As stated throughout, this thesis intends

\footnotetext{
${ }^{144}$ Henry 89.

${ }^{145}$ Henry 49.
} 
to hold Mana Wahine Maori at its centre, and I believe to engage with those texts would transform this into a reactive thesis and simply give yet more space to views to which are unproductive in discussions about Mana Wahine Maori poetry in English.

Although I refuse to engage with the problematics of Pakeha definitions, I will acknowledge some of the problematics of the definition of Mana Wahine Maori. The most important problematic is the risk of marginalization that the section of the term "Wahine Maori" describes. By claiming that all Maori women are representable by Mana Wahine Maori, I might gloss over any differences in position that certainly do exist. For example, Donna Matahaere-Atariki questions her own (and my) privileged position as academic women, and states the concern that by the publication of our personal interpretations of Mana Wahine Maori, we run the real risk of silencing Maori women in less privileged positions. ${ }^{146}$

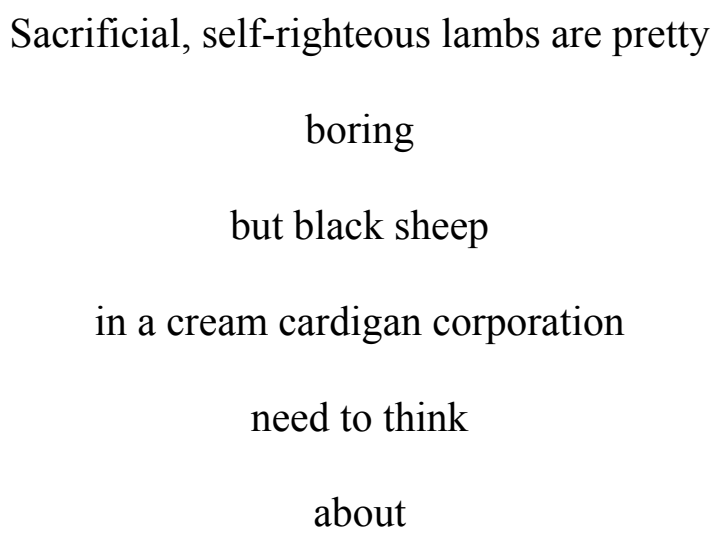

why they are there. ${ }^{147}$

If we as academic women are to proceed with our interpretations of such culturally and thus politically-based terms such as Mana Wahine Maori, then we must also be self-conscious about acknowledging our own potential to marginalise, in order to

\footnotetext{
${ }^{146}$ Donna Matahaere-Atariki, "At the gates of the knowledge factory: voice, authenticity, and the limits of representation," Feminist Thought in Aotearoa/New Zealand: Differences and Connections, eds. Rosemary Du Plessis and Lynne Alice (Auckland: Oxford University Press, 1998): 73.

${ }^{147}$ Potiki, "My Teeth are Saying Goodbye," Shaking the Tree 67(20-26).
} 
avoid becoming one of Potiki's sheep-in-wolves-clothing. The lines "put up with your clever bullying / which passes as "being political"" in "The Decision of the Taniwha" 148 might just as justifiably be addressed to those of us working within the sphere of Mana Wahine Maori as to anyone else. Chapter Four will address this issue of difference in interpretations of Mana Wahine Maori more closely.

The next section of this chapter is an investigation of the experiences that Black American women, Native American and First Nations women, Aboriginal women and Pasifika women have had in pursuing their own projects of literary self-determination, and explores the implications of these various forms of theorizing for Mana Wahine Maori, and by extension, the grouping Mana Wahine Maori Poetry in English. This is a valuable exercise because there are useful lessons to be learnt from these multiple projects whose focus parallels that of Mana Wahine Maori in giving expression to their own culturally-based terms. However, I am certainly not attempting to integrate all of these variant experiences into one 'meta-Indigenous-Feminist critical theory'. I have chosen these four comparative groupings for reasons which I will elucidate at the beginning of each section.

The first grouping that I will discuss is that theorizing around Black American Feminism. I begin here because of the prominence of the writing of Black American feminist women on issues of theorizing their own specific position - as both Black and as Women - in the American literary landscape. Why are they so prominent? Black Americans make up approximately ten percent of the population of the USA. Perhaps because of these great numbers, there has also been a comparatively larger

\footnotetext{
${ }^{148}$ Potiki, "The Decision of the Taniwha" 52(11-12).
} 
amount of publishing on the area of Black American feminist literary studies than there may have been in a smaller country. Black civil rights movements since the 1960s have been widely publicized, both in the USA and abroad, and so, arguably, the audience that such events created for these books is also large. Black American women have been the most widely published in terms of critical writing on white western feminism and the theorizing of difference from that paradigm. In her seminal book Ain't I a Woman: Black Women and Feminism, bell hooks noted the difficulty of theorizing a position that is able to address or deal with the multiple oppressions of race, sex, etc that Black American women suffer. ${ }^{149}$ In contemporary Black American Feminist literary theory, a "paradigm of growth" is now prioritized over a "paradigm of resistance". ${ }^{150}$ Like Mana Wahine Maori, this enables Black American women to theorize their position from a more inherently positive standpoint.

There are several connotations for Mana Wahine Maori of Black American feminist literary theorisings. For instance, the importance of colour, and thus racism to such debates is centred, rather than cultural differences. Black American feminist literary scholars also question the universality of feminist arguments in ways and language which can definitely help (and indeed already have: note the prominence of hooks and Morrison in citation lists of literary scholarship in this country) to inform our own debates regarding the utility of white western feminist theory. The limits of Black American feminist literary criticism for the purposes of this thesis are that Black Americans are not Indigenous to the place in which they now live, and so their discourse is not one that centres on control of land or development. Also the critical terminology used by them is entirely European, and particularly English, and Pan-

\footnotetext{
${ }^{149}$ bell hooks, Ain't I a Woman: Black Women and Feminism (Boston MA: South End Press, 1981) 9.

${ }^{150}$ Ryan, Spirituality as Ideology in Black Women's Film and Literature 16.
} 
African American experience is typically the norm, as opposed to the Iwi/Hapu/Whanau-based divisions to be found in Aotearoa. This means that the Black American Feminist literary discussions do differ in very basic ways from the discussions surrounding Mana Wahine Maori Poetry in English, limiting the potential for experience-exchange. The debt of Mana Wahine Maori literary criticism to Black American Feminist literary criticism however is an important debt of inspiration and influence. Such influence can be seen in Roma Potiki's poem "white boys": "rich white boys in a gang. yes, the gang's name is White Boys. / they hate blacks. they hate us. it's simple..." ${ }^{\prime 151}$ Here "blacks" has suddenly become "us"; usually, in colourcoded discussion of race and culture in Aotearoa, Maori typically describe ourselves as 'brown' rather than 'black', so this signals a strong identification with the binary opposition of black/white used to demarcate race that is commonly found in the USA. $^{152}$

Next, I will discuss the grouping based around Native American and First Nations literary criticism. This grouping is represented prominently in the field of publishing and theorizing about Indigenous literature in English. The Native American and First Nations literary output both creative and critical is large, with a significant number of Indigenous publishing houses available to support such work. There are many important parallels between Native American and First Nations experiences and Maori experiences, as Indigenous, English-speaking minorities in former British Empire colonies, or what has become know as the 'Fourth World'. ${ }^{153}$ The Native

\footnotetext{
${ }^{151}$ Potiki, "White Boys," Stones in Her Mouth, 43(13-14).

${ }^{152}$ The result of such stark polarization is a concurrent sweeping aside of all the other colours of people that reside in the USA.

${ }^{153}$ Chadwick Allen, Blood Narrative: Indigenous Identity in American Indian and Maori Literary and Activist Texts (Durham and London: Duke University Press, 2002) 9.
} 
American and First Nations spiritual connection to the land ${ }^{154}$ and the figuration of that connection into literature is also a site of intersection with Maori experience, ${ }^{155}$ as the recognition of the importance of prioritizing tribal experience over a pan-Native North American experience. ${ }^{156}$ Native American and First Nations women have also been developing their own Indigenous critical literary frameworks: Paula Gunn Allen refers to the particular methodology that she uses as "tribal-feminism or feministtribalism." ${ }^{157}$ Roma Potiki's poem "Crow Woman" enacts these kinds of intersections with a description of experience that, were it not for certain words positioning this as a poem addressed to a Native American and First Nations woman, might just as well be addressed to a Maori woman:

old, old walking.

She finds it painful to keep sipping

the medicine

and hoping that it will work

wonders.

Will we never cease

\footnotetext{
${ }^{154}$ Patricia Clark Smith and Paula Gunn Allen, "Earthly Relations, Carnal Knowledge: Southwestern American Indian Women Writers and Landscape," "Yellow Woman": Leslie Marmon Silko, ed. Melody Graulich (New Brunswick: Rutgers University Press, 1993)115-150: 116: "American Indian people ... live in the context of the land."

${ }^{155}$ Smith and Allen, "Earthly Relations, Carnal Knowledge: Southwestern American Indian Women Writers and Landscape," 116: "Their literature thus must be understood in the context of both the land and the rituals through which they affirm their relationship to it."

${ }^{156}$ Throughout her book, Devon Abbott Mihesuah makes practical room for the pluralistic experience of Native Americans, rather than resorting to easy, but false generalisations. For instance, when she gives examples of the traditional powers of Native American women, she says: "In Iroquois tribes, for example, women controlled the economy and the politics", and "In traditional Cherokee society, women decided how to punish transgressors". Devon Abbott Mihesuah, So You Want to Write about American Indians? A Guide for Writers, Students, and Scholars, (Lincoln: University of Nebraska Press, 2005) 18.

${ }^{157}$ Allen, Paula Gunn, The Sacred Hoop: Recovering the Feminine in American Indian Traditions, (Boston: Beacon Press, 1986) 222.
} 
the work. Stamping the ground

and clearing the air.

This poem is a description of the 'bitter medicine' of colonialism, delivered through such avenues as schooling, by which Indigenous people were exhorted to participate in their own assimilation into colonial society. It is also an acknowledgement of the great age of these cultures and the respect that is traditionally accorded to elderly people. The poem also refers to the stamp dance that is performed in many Native American and First Nations tribes, and uses that dance as a metaphor: when the air is clear, and women have done the work of writing themselves, the people will be seen as they truly are - through their own lenses. This letter to Native American and First Nations women is answered by Gunn Allen, who holds out a hand of welcoming recognition: "The sense of the connectedness of all things...is the identifying characteristic of American Indian tribal poetry. These features link American Indian literary work to that of tribally inspired poetry around the world." 158

There are some important implications of Native American and First Nations feminist literary theorisings for Mana Wahine Maori. For example, they support as a priority the development of Indigenous epistemologies that are centred on tribal experiences. If Mana Wahine Maori were to follow such a path, it might well become Mana Wahine Iwi. However there are also limitations to the application of Native American and First Nations lessons. Using the previous example, the large number of distinct Native American and First Nations tribal languages means that that the development of tribally-based epistemologies has an urgency that arguably the Iw/Hapu/Whanaubased development of knowledge does not have. Contributing to the prioritisation of

${ }^{158}$ Allen 167. 
tribal epistemology is the reservation experience, which, although seemingly similar to our marae are differentiated by their legal status as tribal centres. In contrast, Native Americans/First Nations do not a document similar to te Tiriti that entrenches their legal right to self-determination. Arguably, this has provided some of the impetus in the past for the prioritising of Maori experiences over tribal ones.

There are also some useful parallels between Mana Wahine Maori and the groupings around Australian Aboriginal feminist critical literary theories. Because of their geographical proximity and a similarity of certain elements of colonial experience (in the time of settlement and the origins of those settlers), there are intersections between our cultures and histories that are reflected in the Indigenous literary methodologies that we have both developed. In "Shaking the Tree", a poem that explores the experience of the 'stolen generation' of Australian Aboriginal children, Roma Potiki writes that "She sees things that will last for generations." "159 Just like aboriginal knowledge, aboriginal experiences are passed down through the generations: these things will last, because they will not be forgotten. Here, too, Potiki recognises these sorts of connections that exist between Indigenous women:

In a silent space

a woman embraces the wattle tree, its pink sap runs in her veins maps the direction to be shared. ${ }^{160}$

The shared route is the parallel journeys towards self-determination that Indigenous women embark on by theorizing our experiences. The space, the 'terra nullus' is silent no longer, and was never really silent at all - women have always defined themselves.

\footnotetext{
${ }^{159}$ Potiki, "Shaking the Tree," Shaking the Tree 36-37(22).

${ }^{160}$ Potiki, "Shaking the Tree," 36-7(10-13).
} 
When Anita M. Heiss argues that “....any definition of Aboriginal writing should be coming from Aboriginal writers themselves" $" 161$ she is not only fighting back against the assimilationist tendencies of a 'canon' of literary criticism that is non-Indigenous, but also against the assimilation of Australian Aboriginal experience, such as that forced on the stolen generation. Again, there are clearly implications for Mana Wahine Maori of Australian Aboriginal feminist literary theorising, such as that performed by Heiss. There is a confidence of identity about Australian Aborigine feminist writing that refuse to admit any 'outsider' criticism of its methods. Heiss writes of the Aborigine-run organisations that have produced their own identity cards to counter against the exploitation of opportunities for Aborigines by nonAborigines. ${ }^{162}$ However this is also an example of the limitations in applicability of Australian Aboriginal feminist critical literary theories for Mana Wahine Maori. If Aboriginal writers and critics must produce identification cards, what does this mean for mixed-race experiences? Is there a place for them in the writing of Aboriginal experience?

Finally, the groupings around Pasifika feminist literary criticism also have productive intersections for Mana Wahine Maori literary criticism. I have left these Pasifika groupings until last, because I believe that their experiences are the most similar to those moments that make up Mana Wahine Maori experiences. We have shared a language base, a shared geneology and we also share a great deal of cultural elements, such as our stories about our common ancestor, Maui. Therefore, I think that the lessons of Pasifika feminist literary criticism may be the ones from which we can take the most immediately applicable experiences. As an example of this possible

\footnotetext{
${ }^{161}$ Heiss 26.

${ }^{162}$ Heiss 18.
} 
applicability, Katerina Martina Teaiwa prescribes that in order to know Pasifika history the reading of land/seascapes is essential. That is, not only a visual reading of those spaces, but a reading of the creative writing that is based in the land and ocean, because as we know by now, all forms of Indigenous writing are 'political' ${ }^{163}$ The lesson for Mana Wahine Maori as a critical methodology is to realise that all of our writing output - poetic, fictional, factual, critical is telling us who we are, not matter what words it uses. This is an important observation of the centrality of context to Indigenous writing. ${ }^{164}$

As with the other groupings of Black and Indigenous Feminist literary criticism, there are also inferences for Mana Wahine Maori of Pacific feminist literary theorising. Selina Tusitala Marsh is one of those at the centre of this grouping, and her article "Ancient Banyans, Flying Foxes and White Ginger: The Poetry of Pacific Island Women"165 focuses on the development and application of a feminist Pasifika methodology for literary criticism. She wrote that she was inspired in this project by Mana Wahine Maori. However, in another article, she writes of Mana Wahine Maori that it: “...is more than just a postcolonial, feminist theoretical creation. Indeed, in many ways it is "antitheoretical" because theory is popularly seen, in Mita's words, as the "objective approach to that subject matter" while Mana Wahine for her is the

\footnotetext{
${ }^{163}$ Katerina Martina Teaiwa, "Our Sea of Phosphate: The Diaspora of Ocean Island," Indigenous Diasporas and Dislocations, eds. Graham Harvey and Charles D. Thompson Jr. (Aldershot: Ashgate Publishing Limited, 2005) 189.

${ }^{164}$ Konai Helu Thaman, "Of Daffodils and Heilala: Understanding (Cultural) Context in Pacific Literature," Navigating Islands and Continents: Conversations and Contestations in and around the Pacific, eds. Cynthia Franklin, Ruth Hsu and Suzanne Kosanke (Honolulu: College of Languages, Linguistics and Literature, University of Hawai'i and the East-West Center. 2000) 40-50: 42: "Sometimes when I read reviews of books by Pacific authors, I am struck by the obvious lack of understanding or the work in relation to the context in which it is written."

${ }^{165}$ Selina Tusitala Marsh, "Ancient Banyans, Flying Foxes and White Ginger: The Poetry of Pacific Island Women," Bitter Sweet: Indigenous Women in the Pacific, eds. Alison Jones, Phyllis Herda and Tamasailau M. Suaalii (Dunedin: University of Otago Press, 2000) 137-159.
} 
"subjective distillation of my experience."166 While I certainly agree with Marsh that Mana Wahine Maori was not created by feminist or postcolonial theories, I must engage with her statement that Mana Wahine Maori is "antitheoretical." As I have shown so far, it is actually a very theoretically-based (amongst other factors) methodology, which embraces subjective, pluralistic experiences. I think that the use of this word "antitheoretical" in this situation unintentionally reinscribes the criticism of the "simplicity" of Indigenous verse, and unfortunately extends that simplicity to theory. However, I do agree with her focus on the importance of the subjective experience when formulating literary theory: it is our experiences of ourselves that must continue to inform the development of our Indigenous epistemologies. There are other implications for the use of Pasifika feminist literary criticism in Mana Wahine Maori. Pasifika peoples are the numerical majority in their countries and their governments are also largely of Pasifika descent; they have experienced little loss of language or tradition, in comparison with Maori, neither has urbanisation been such a significant element of change. All of this in combination produces a social, cultural and political climate that serves to differentiate Pasifika experiences from Maori experiences, and so the climate in which Pasifika feminist literary critical theorizing has developed. At this stage it is uncertain what these differences might mean, but is a reminder that we cannot uncritically adopt all of the same positions and assertions made by Pasifika feminists and apply them to Mana Wahine Maori, simply because of our similarities. Nonetheless, there are more connections between us than not, and the following extract from Roma Potiki's poem "Pirates", in which she talks of "Pacific women as beautiful as / plump sirloin marinated in guava"167 bears this out:

\footnotetext{
${ }^{166}$ Selina Tusitala Marsh, "Migrating Feminisms: Maligned Overstayer or Model Citizen?” Women’s Studies International Forum 21.6 (1998) 665-680: 674.

${ }^{167}$ Potiki, "Pirates," Shaking the Tree 72-3(6-7).
} 
Festooned on a coral rock

or shaft-eyed above the bush

and clasped hands

and word waterfalls

tumbling us together - precious. ${ }^{168}$

Pasifika feminist literary critical theorising and Mana Wahine Maori are indeed word waterfalls: each originating in a separate stream perhaps, but powerfully united in their common aim of literary self-determination.

${ }^{168}$ Potiki, "Pirates," 72-3(46-50). 


\section{AND IN THE HOWL OF A CLEANSING WIND / \\ AND THE SURGE OF POWERFUL CURRENTS/ YOU WILL BE CARRIED TO MEET YOUR CREATION.}

The previous chapters have offered a definition of the principles of Mana Wahine Maori critical theory. The purpose of this has been to illustrate why the grouping and naming of certain texts - of which the poetry of Roma Potiki is an example - as Mana Wahine Maori Poetry in English, creates a valuable new way of reading these texts. Such readings simultaneously recognise both the poems' identity as Mana Wahine Maori Poetry in English, and the multiplicities inherent within such a definition. Like the poem "Decision of the Taniwha" this chapter signals and, with a change in tense from past to future, and describes some of the work that remains to be performed in reading such texts. ${ }^{169}$ The word "multiplicities" may thus usefully act as the conceptual rock around which the winds, or strands of Mana Wahine Maori poetry in English storm.

The multiplicities I discuss in this chapter include: Whanau/Hapu/Iwi-specific readings of Mana Wahine Maori Poetry in English; Urban Maori-specific readings and queer-specific readings. There are numerous other readings that may be usefully performed, such as readings of reo speakers compared with non-reo speakers, and readings that focus on the significance or not of the generation the poet belongs to, but these first three have been highlighted as they are amongst what I consider to be the most critically-debated strands. Mana Wahine Maori critical theory and, consequently, Mana Wahine Maori poetry in English are not prescriptive 'categories'.

\footnotetext{
${ }^{169}$ That further such readings are not performed in-depth within this thesis, is due both to a lack of space and an acknowledgement that different readers will obviously bring different insights from those that I am able to offer here: for example, a Te Aupouri woman reader born in the late fifties may well prioritise certain elements of Roma Potiki's poetry that I, as a Tamatarangi/Ngati Kahungunu ki Te Wairoa woman reader born in the late seventies, do not.
} 
Whilst it may be possible to point out certain elements they encompass - the kaupapa of Mana Wahine Maori poetry in English - and indeed, it has been the aim of this thesis to do so, it would be misleading to term such elements as 'principles', the possession of which would admit a text entrance to the exclusive, enclosed box that a word such as 'categories' evokes. The phrase 'critical theories' however may be far more useful, suggestive as it is of multiplicities and pluralities. As Kathie Irwin put it, "There is no one theory of Maori feminism; there will be many." 170

Irwin was referring in particular to the prioritising of Whanau/Hapu/Iwi-specific readings of texts, above a generalised 'Maori-reading'. The following section will examine the implications, and importance, of such specific readings. Iwi, Hapu and Whanau: the simple existence of these terms problematizes the word 'Maori', and so must necessarily also be used to complicate the idea of Mana Wahine Maori. As John Rangihau pointed out from as early as 1975, often the grouping 'Maori' can be a dangerously simplistic one:

I have a faint suspicion that Maoritanga is a term coined by the Pakeha to bring the tribes together. Because if you cannot divide and rule, then for tribal people all you can do is unite them and rule, because then they lose everything by losing their tribal histories and traditions that give them their identity. ${ }^{171}$

Related to each other by whakapapa in ascending order of proximity, iwi, hapu and whanau also often share specific kawa that differentiates them from other iwi, hapu or whanau, and allows their common grouping to be discussed beyond the merely genealogical. Iwi/hapu/whanau divisions are also political divisions, and are vitally important as such, as illustrated by the uncompromising remarks of Powhiri

\footnotetext{
${ }^{170}$ Irwin, "Towards Theories of Maori Feminism," 6.

171 John Rangihau, "Being Maori," Te Ao Hurihuri: The World Moves On, ed. Michael King (Wellington: Hicks Smith \& Sons, 1975) 221-233: 233.
} 
Wharemarama Rika-Heke: "I am not Maori. I belong to a group of people which comprises iwi or tribes, each tribe an independent sovereign nation. I am Ngati Hine..." ${ }^{172}$ As will be shown, an understanding of specific kawa and whakapapa may certainly be used to inform some new and valuable readings of Mana Wahine Maori poetry in English texts. Before proceeding however, it is necessary to explain why, if this would provide such an informative reading of Mana Wahine Maori poetry in English texts, I have not performed such a reading of Roma Potiki's work myself, since a in-depth reading of her poems is at the centre of this thesis. I used Potiki's poem "the unemployed march" as a critical statement informing my decision not to approach her work from a iwi perspective:

oh yes

collected tribes of Aotearoa,

stripped of our belongings and left wanting,

our time is now. ${ }^{173}$

This poem compares an unemployment protest march on Parliament to the 1975 Hikoi, with the conclusion that in both cases it is Maori - as a whole - who are being cheated by the government, Maori who will once again be left with nothing, Maori who will have to act together in order to be powerful enough to challenge the imposed status quo, in literature as in politics. Also, as established at the outset, Roma Potiki is of Te Aupouri, Te Rarawa and Ngati Rangitahi. Although my own iwi affiliations (I am of the iwi Ngati Kahungunu ki Te Wairoa, and the hapu Tamatarangi) mean that I cannot occupy the position of true insider in an investigation of her texts, this

\footnotetext{
172 Powhiri Wharemarama Rika-Heke, "Margin or Center? "Let me tell you! In the Land of my Ancestors I am the Centre": Indigenous Writing in Aotearoa," English Postcoloniality: Literatures from around the world, eds. Radhika Mohanram and Gita Rajana (Westport: Greenwood Press, 1996) 151.

${ }^{173}$ Potiki, "the unemployment march," Stones in Her Mouth 58(13-16).
} 
certainly doesn't preclude me from a useful investigation which remains sensitive to such factors. ${ }^{174}$ Ella Henry and Hone Pene take such debate to its logical conclusion:

This raises some, as yet unanswered, questions for, in a re-tribalised Maori society, are research, knowledge and its transmission to be confined solely to members of particular groups? Can Maori knowledge be considered a universal knowledge for all Maori and other Indigenous peoples? Are other Maori able to access both the knowledge and the tribal knowledge institutions? ${ }^{175}$

However, where the position of insider is useful though is in enacting a responsibility towards their own Iwi/Hapu/Whanau to prioritise their own Iwi/Hapu/Whanau stories. Creek scholar Craig Womack defines his position as tribal insider thus: "My purpose in writing Red on Red is to contribute ... toward opening up a dialogue among Creek people, specifically, and Native people, more generally..."176 It is debatable whether or not an Iwi/Hapu/Whanau 'outsider' would feel the same responsibility.

The utility of such specific readings of texts, and its implications for the grouping of Mana Wahine Maori poetry in English may be seen in the active critical discussions regarding the 'speaking rights' of Maori women on the marae. ${ }^{177}$ Ngahuia Te Awekotuku, of Te Arawa, has been one of the most vocal protestors against what she terms as the inherently sexist restriction, amongst many iwi, against women

\footnotetext{
${ }^{174}$ However, it is certainly to be hoped that people with these qualifications - ie, from the same iwi as Roma Potiki - will someday publish an examination of her work from this perspective that goes beyond the general perspective herein established.

${ }^{175}$ Henry and Pene 240.

${ }^{176}$ Womack, 1.

${ }^{177}$ I have placed the phrase 'speaking rights' in apostrophes in order to acknowledge the fact the most Mana Wahine Maori critics have interrogated this phrase; to highlight the different interpretations of 'speaking' that can be seen in the following examples, and also to question the rigid oppositionality that the word 'rights' imposes: that is, that one is either given permission to perform this action, or is denied it.
} 
performing the whaikorero on the marae. ${ }^{178}$ Mira Szaszy also published articles and papers of this view, suggesting that the result of such restrictions went beyond mere protocol: “...denial of marae speaking rights implied denial of leadership potential." 179

Kathie Irwin interrogates the phrase 'speaking rights' and the concept's abuse by mainly Pakeha feminists. ${ }^{180}$ She is one of a number of Mana Wahine Maori critics who have argued that the relation of this phrase purely to the whaikorero, and the restriction of the whaikorero in many iwi to men, ignores the speaking rights inherent such activities as the karanga, waiata and tangi. ${ }^{181}$ The point that she and other critics make is one of 'separate, but equal' areas of importance between women and men on the marae. However, she also goes on to criticise the iwi who still refuse to allow women to whaikorero as sexist: "The role and status of women remains petrified, like a slab of rock, unchanging, immobile, inflexible..."182 Other Mana Wahine Maori critics offer yet a different perspective. Ella Henry is one of a number such critics whose analysis of pre-colonisation Maori society denies that Maori culture was traditionally sexist. Expanding on a comment that women were traditionally powerful only 'behind the scenes':

The implicit assumption here, however, is that 'behind the scenes' is less significant than 'in-front' of the scenes. But, ideas about 'behind' and infront', are saturated with Western values associated with public and private spheres of activity. If Maori women were powerful 'behind the scenes', it may well be that 'behind the scenes' was a meaningful locus of political activity

\footnotetext{
${ }^{178}$ Such statements can be seen throughout the essays in her collection of writings: Te Aekotuku, Mana Wahine Maori: Selected Writings on Maori Women's Art, Culture and Politics.

${ }^{179}$ Mira Szászy, from Me Aro Koe ki te Ha o Hine-ahu-one, Te Ao Marama 2 Regaining Aotearoa: Maori Writers Speak Out, ed. Witi Ihimaera (Auckland: Reed Publishing, 1993) 287 - 291.

${ }^{180}$ Irwin, "Towards Theories of Maori Feminism" 12.

${ }^{181}$ Irwin, "Towards Theories of Maori Feminism" 12.

182 Irwin, "Towards Theories of Maori Feminism" 17.
} 
and control, given there is no evidence that the public and the private were assigned the same meanings in traditional Maori society, as they are in Western society. ${ }^{183}$

In this interpretation, it was often Maori women, rather than Maori men who possessed true 'power', regardless of who gave the whaikorero. However another Mana Wahine Maori critic, Te Kawehau Clea Hoskins, places a strong qualification on such statements, and brings the debate back to one centred around Iwi/Hapu/Whanau specificity. She suggests that critics who make such claims of traditional female power (in area such as the 'right' to whaikorero) are, in the main, overly-influenced by the "'high' status" of women their own iwi into making generalisations about the strong position of all Maori women in traditional society. ${ }^{184}$ However, she then goes on to suggest that such generalisations are fully conscious acts of political intent:

Maori women ourselves have been articulating the past and deploying identities as a form of resistance in order that we will share more equally in a collective political vision. ${ }^{185}$

The implications of such debates for reading the texts of Mana Wahine Maori poetry in English are clear. The Iwi/Hapu/Whanau stories, perspectives, norms and kawa of a reader are very likely to influence their interpretation of the Mana Wahine Maori elements in a poet's work: if their Iwi/Hapu/Whanau differs from that of the poet's, then they may well place a different significance on certain aspect of those poems that a reader with a whakapapa closer to the poet's might do. John Rangihau is emphatic that such differences can preclude a reader's full identification with a text:

\footnotetext{
${ }^{183}$ Henry, 89.

${ }^{184}$ Te Kawehau Clea Hoskins, "In the Interests of Maori Women?: Discourses of Reclamation," Bitter Sweet: Indigenous Women in the Pacific, eds. Alison Jones, Phyllis Herda and Tamasailau M. Suaalii (Dunedin: University of Otago Press, 2000) 39.

${ }^{185}$ Hoskins 39.
} 
Each tribe has its own history. And it's not a history that can be shared among others. How can I share with the history of Ngati Porou, of Te Arawa, of Waikato? Because I am not of those people. I am a Tuhoe person and all I can share in is Tuhoe history. ${ }^{186}$

I will suggest however that the texts that may be read as part of the grouping Mana Wahine Maori Poetry in English, because they are not themselves (typically) tapu sources of information, probably allow a much greater level of identification across Iwi/Hapu/Whanau boundaries, than the example that Rangihau provides.

Iwi/hapu/whanau-specific readings may not be as useful however when looking at the poetry by urban Maori women. There are two particular examples that I will examine here. The first is the urban Maori woman raised away from her traditional iwi land. This particular woman is aware in a general way of her whakapapa - that is, she may know who she is directly descended from, back several generations, and she knows the name of her iwi and perhaps even her hapu - but she was not raised knowing the kawa, stories and history particular to them. The second example of an urban Maori woman is one who knows only that she is Maori, but not who her parents' people were, and so is unaware of her own iwi identification. The most pertinent question here must be: would either of these women's poetry be able to be read as examples of Mana Wahine Maori Poetry in English? Thomas King has raised the same questions of interpretation in regards to the writing of urban-born and raised Native Americans and First Nations peoples. He says:

Many no longer speak their Native language, a gift of colonialism, and the question of identity has become as much a personal matter as it is a matter of

\footnotetext{
${ }^{186}$ Rangihau 232.
} 
blood. N. Scott Momaday has suggested that being Native is an idea that an individual has of themselves. Momaday, who is Kiowa, is not suggesting that anyone who wants to can imagine themselves to be Indian. He is simply acknowledging that language and narrow definitions of culture are not the only ways identity can be constructed. ${ }^{187}$

His suggestion then, is for a writer's cultural identity, and its expression in their texts to be respected as if they had been raised in a more 'traditionally native way'. The impact of such an assertion on the readings of their texts is an important one. It avoids judging the worth of a text in direct relation to the perceived 'authenticity' of the author, which is a mistake that Indigenous scholars have abhorred in such critical writings as C.K. Stead's interrogation of Keri Hulme's the bone people. Rather than internalising and repeating such misreadings, respecting a writer's identity enables useful readings of their texts, no matter what their background. As Patricia Clark and Paula Gunn Allen point out: “American Indian people - even urban dwellers - live in the context of the land. Their literature thus must be understood in the context of both the land and the rituals through which they affirm their relationship to it." ${ }^{188}$ Albert Wendt suggests that Indigenous readings of urban-generated and informed writings are not only useful, but that in fact these texts should be held at the centre of contemporary literary scholarship. He begins with the significant point that we are ourselves responsible for the construction of the period of our cultures that we then name 'traditional'. ${ }^{189}$ As such, we also have the power to determine what our contemporary culture should look like, rather than be constrained by the maintenance of a self-constructed 'authentic' tradition: "Our quest should not be for a revival of

\footnotetext{
${ }^{187}$ Thomas King, The Truth About Stories: A Native Narrative (Toronto: House of Anansi Press, 2003) 54.

${ }^{188}$ Smith and Alllen 116.

${ }^{189}$ Albert Wendt, “Towards a New Oceania," A Pacific Islands Collection: Seaweeds and Constructions 7 (1984): 75.
} 
our past cultures but for the creation of new cultures which are free of the taint of colonialism and based firmly on our own pasts. The quest should be for a new Oceania." ${ }^{190}$ In her poem "This Woman Fine", Roma Potiki begins by saying "There are women now, in tune."'191 'In tune' is suggestive of correctness and harmony, and the title seems to reassure the reader that, yes, this/these women are doing just fine. In the next few lines she explains who these heroines are:

Women who have not been trained in time

but out of step

with their own footfalls,

booting themselves along the city streets. ${ }^{192}$

They are urban Maori women, not raised with 'traditional' Maori culture, "out of step", but nonetheless confidently surviving and striding out, "booting themselves along" in a contemporary landscape. The indignant question that comes next is aimed at the traditionalists who, with their 'correct' ways of being Maori would seek to undermine the legitimacy of urban Maori culture: "Who are you / to come with rural gifts / saying you have a story that will show us the way?" 193 She follows this with an illustration that all ways of telling Maori experiences are genuine: "the shelter is both sky and earth, / all on, below, between and above are the story -". ${ }^{194}$ No matter where we were raised and what our experiences of being Maori are, Ranginui and Papatuanuku envelope us all. Potiki herself relates such experience back to Mana Wahine Maori Poetry in English, pointing out: "Our [theatre] group works within a Maori framework, but it's easy to say this without really understanding what 'Maori

\footnotetext{
${ }^{190}$ Albert Wendt 76.

${ }^{191}$ Potiki, "This Woman Fine," Shaking the Tree 50(1).

192 Potiki, "This Woman Fine," 50(2-5).

${ }^{193}$ Potiki, "This Woman Fine," 50(6-8).

${ }^{194}$ Potiki, "This Woman Fine," 50(17-18).
} 
framework' actually means."195 For our purposes the 'Maori framework' is Mana Wahine Maori Poetry in English, and as the poem has shown, this grouping must enable readings of the poetry urban Maori women - otherwise, it cannot rightly use the descriptive phrase 'Mana Wahine Maori'.

Finally then, there is also a great tradition of writing by Takatapui Maori women that places them firmly in the centre of Mana Wahine Maori discussions. Unarguably one of the key writers in the whakapapa of Mana Wahine Maori is Ngahuia Te Awekotuku. Her works, both creative and critical, are foundational texts for both this area and this thesis in particular. Mana Wahine Maori ${ }^{196}$ has certainly been the main inspiration for much of the current work on Mana Wahine Maori issues in general, as well as Takatapui concerns in particular. Not only one of the first to popularise the term Mana Wahine Maori with her articles and papers back in the 1970s, she was also one of the first to talk of "seizing the power" of self-definition, not only for Takatapui Maori women but for all Maori women. ${ }^{197}$ It seems quite possible that she was one of the sources of inspiration for Roma Potiki's "That Maori Girl”:

That Maori girl's a radical y'know

she doesn't like men

and she doesn't like whites.

Bet she's one of those lezzies, needs a bloody good ... if yer ask me.

Thats what's wrong with her... ${ }^{198}$

\footnotetext{
${ }^{195}$ Potiki, "He Wahine Kaimahi Whakangahau," 115.

${ }^{196}$ Te Awekotuku, Mana Wahine Maori.

197 Te Awekotuku 62-3.

${ }^{198}$ Potiki, “That Maori Girl," Stones in Her Mouth 11(1-3/15-16).
} 
Positioned as 'radical' because of a self-definition that doesn't centre males or Pakeha, "That Maori Girl” clearly fits into discussions regarding Mana Wahine Maori, and so Mana Wahine Maori also seems to fit neatly into discussions of Takatapui. The reference to "lezzies" as "wrong", which comes from the mouth of the poem's racist, sexist, homophobic speaker serves to inscribe the 'rightness' of Takatapui. This term is not a binary construction of oppression however, but an embracing of the positive values that remain unspoken in the poem. In "Toetoe Turn", Potiki writes of a procession of kuia heading: "to the meeting places / the heaving rocks / where she\&he she\&she he\&he might be found."199 The aim of the procession is not exposure, but a reminder of the traditional acceptance of Takatapui. The participation of other key Maori Takatapui women writers, such as Cathy Dunsford in the formulation of Mana Wahine Maori writing is fascinating and deserves much closer discussion than I can provide here. Takatapui Maori women have always been at the foundational centre of Mana Wahine Maori, just as they have always been in traditional Maori society:

In the name of Maori development, Maori lesbians and gay men have been subject to a process of cultural ridicule and abuse from those who would have us believe that homosexuality was unknown before the arrival of the Pakeha, and who have labelled it as another anti-Maori practice.... What we have learnt from our Pakeha colonizers is homophobia, how to fear and hate those lesbians and gay members of our whanau whom we have historically accepted and loved. ${ }^{200}$

Neither is such traditional acceptance and appreciation of Takatapui unique to Maori society: Fa'afafine have always been visible and significant members of Samoan

\footnotetext{
${ }^{199}$ Potiki, "Toetoe Turn," Shaking the Tree 24-25(14-16).

200 Kathie Irwin, "'Challenges', to Maori Feminists," Broadsheet: Twenty Years of Broadsheet Magazine (Auckland: New Women's Press, 1992) 82.
} 
society, and Paula Gunn Allen illustrates that same-sex relationships have always been central in American Indian culture too. ${ }^{201}$ The implications of this for the readings of Mana Wahine Maori poetry in English are significant: clearly, Takaaapui features in such readings are not indicative of a progressive attitude towards Takatapui Maori women, but rather evidence that they are in the centre of this grouping - right where they started, and 'right' where they have always been.

The purpose of this chapter has been to complicate the kaupapa of Mana Wahine Maori Poetry in English, as set out in the preceding chapters. The point is not to invalidate this kaupapa, but rather to make clear that it is not set in stone, solid and immutable. Indeed, for one set of factors to apply to the exclusion of all others would put - to adopt the title of Roma Potiki's first collection - "stones in her mouth", and again perpetuate the cycle of 'speaking for': this time, speaking for Potiki. This pluralism of approaches does not seem to have proved a problem so far - such differences are reflected in the privileging of different principles by those scholars working in a Mana Wahine Maori context. Despite a refusal to lay down fixed principles, one general and central tenet of Mana Wahine Maori scholarship is nevertheless obvious: to adapt the words of Pihama, Cram and Walker in their article on 'Creating Methodological Space', it is the "affirmation and legitimation of being" a Maori woman. ${ }^{202}$ Roma Potiki's poem "Plummet" can be used as an example of the almost exhausting complexity of Mana Wahine Maori critical theories, and the huge variety of works that might make-up Mana Wahine Maori Poetry in English, but may also be taken as encouragement to continue the work, for at least that work is our own creation:

\footnotetext{
${ }^{201}$ Allen 196-200; 245-260.

202 Pihama, Cram and Walker 30.
} 
Crazy wind and stinging sand

let me exhaust it all

till I feel something warm on my face

other than the burn of tears ${ }^{203}$

It is to be hoped that any future tears caused by reading the poems of Maori women are of joy at the amazing adaptability and skill of these poets at representing the innumerable variations of our experience.

${ }^{203}$ Potiki, "Plummet," Shaking the Tree 19(14-17). 


\section{IT IS YOU WHO CALLED THE TANIWHA / AND YOU WHO WILL HAVE TO WORK FOR RELEASE.}

The taniwha 'Mana Wahine Maori poetry in English', has been named/called in/to this thesis: the next stage needed, then, is a release. Having illustrated that reading Roma Potiki's work in relation to this grouping of works is indeed a rich and useful new way of examining her work, that release might well be found in the following question: are the arguments made in this thesis in any way applicable to the poetry of other Maori women? Clearly a complex analysis of this question in relation to every Maori woman poet is outside of the scope of this thesis. Its main focus has necessarily been an in-depth investigation of one woman's poetry, aiming to provide a close reading both of her poetry, the scholarship and the grouping that I have produced as a result of their interaction. However, I will contend that this grouping provides equally rich insights when used in conjunction with the work of other Maori women poets. To this end, this final chapter will discuss the work of Keri Hulme. In order to support this contention, I will use examples drawn from Keri Hulme's poetry, in particular from the two collections The Silences Between: Moeraki Conversations ${ }^{204}$ and Strands. $^{205}$ Additionally, I will further examine the contention made briefly in Chapter One that this grouping can also support an expansion into 'Mana Wahine Maori writing in English', which would encourage readings of an author's work across their entire oeuvre.

Firstly however, it is important to establish the reasoning behind the choice of Keri Hulme's work for this chapter. In November 2005 I was invited to present a paper at a

\footnotetext{
${ }^{204}$ Keri Hulme, The Silences Between (Moeraki Conversations) (Auckland : Auckland University Press; London: Oxford University Press, 1982) .

${ }^{205}$ Keri Hulme, Strands (Auckland: Auckland University Press, 1992).
} 
symposium marking the twentieth anniversary of the bone people ${ }^{206}$ winning the Booker prize. The event was well publicized: advertising appeared on the Victoria University website (the conference location), in the local papers, and was also referred to on a television arts show. I began thinking about the implications of such an event: what did it mean that the bone people and its author had been singled out in this way? And when might there be a similar event to mark the achievements of Roma Potiki's work, or of J.C. Sturm's work, or any of the many other Maori women writers? I doubt it controversial to state that there wouldn't be a comparable event unless they were also to win a major international literary prize. As a result of this event, I started researching more closely the area of canon-formation. ${ }^{207}$ In relation to the "traditional New Zealand literary canon', which I have already discussed in this thesis and will talk further, I was very interested to note that the only Pakeha male at the conference, and one of only three men in total, was the managing director of a publishing company with whom Hulme had recently worked. None of this country's frequentlypublished male poets, reviewers or critics were present. ${ }^{208}$ So whilst undoubtedly a well-known, and therefore 'visible' public figure in certain respects, she remains (partially of her own volition, certainly) an almost misplaced person at times, often featuring in "Whatever happened to...?" newspaper and magazine filler columns. The same can clearly be said of her writing: from the public adulation (voted number 20 on the Whitcoulls List - Top 100 Books in New Zealand) of her oft-reprinted and

\footnotetext{
${ }^{206}$ Keri Hulme, the bone people (Auckland: Spiral; Hodder \& Stoughton, 1985).

${ }^{207} \mathrm{I}$ also looked at the publishing and sales statistics and the representation in New Zealand university English courses of books by Maori women writers:

${ }^{208}$ Here it is interesting to note Mark Williams' comments in Williams, Leaving the Highway: Six Contemporary New Zealand Novelists (Auckland: Auckland University Press, Auckland: 1990) 196: Certainly, Keri Hulme, for all the rhetorical antagonism her novel directs at Pakeha 'monoculture', is not outside Pakeha culture as Mulgan, Hyde, Sargeson, Gaskell and Hilliard were. Her criticism was assimilated remarkably swiftly and her book appeared on University English courses within three years of publications.

If Hulme was such a successfully accepted member of 'the canon', then surely such across-the-board absences of Pakeha men from such a significant event can not be put down to mere coincidence.
} 
translated novel the bone people, to the single print-runs of her little-reviewed poetry volumes. This curious juxtaposition between visibility and invisibility, discussed in Chapter One in relation to Roma Potiki's poetry and operating in a very similar way here, is the main reason why I now choose to involve Keri Hulme's work in this context.

To return to the discussion around genre, first raised in regards to Roma Potiki's work in Chapter One, it seems quite obvious that similar genre-related questions and issues regarding 'canon-making' arise when looking at the lopsided critical attention paid to her published poetry as compared with her novel the bone people. Although simplistic, a purely quantitative comparison illustrates the extent to which this is the case. The Silences Between (Moeraki Conversations) was published in 1982. Only four published articles have directly reviewed this book. ${ }^{209}$ Later, Lost Possessions $^{210}$, published in 1985 after the bone people won the Booker Prize, was directly reviewed six times ${ }^{211}-$ an increase on the previous collection, but certainly not a number that would typically be expected of an author's first work published after such a major award. $^{212}$ Furthermore, Strands, published in 1992, garnered ten separate reviews, which would seem to be a great improvement. ${ }^{213}$ In comparison with the number of reviews for the short story collection Te Kaihau/The Windeater ${ }^{214}$ though (published

\footnotetext{
${ }^{209}$ New Zealand Literature File: Keri Hulme, The University of Auckland Library, 15 Apr. 2006 $<$ http://www.library.auckland.ac.nz/subjects/nzp/nzlit2/authors_az.htm $>$.

${ }^{210}$ Keri Hulme, Lost Possessions (Wellington: Victoria University Press, 1985).

${ }^{211}$ An interesting investigation could well be performed here analyzing the timelines over which these texts were written and whether that might/should affect any discussions of them. Unfortunately, space prevents me from performing such an investigation here.

${ }^{212}$ New Zealand Literature File: Keri Hulme, The University of Auckland Library, 15 Apr. 2006 $<$ http://www.library.auckland.ac.nz/subjects/nzp/nzlit2/authors_az.htm >.

${ }^{213}$ New Zealand Literature File: Keri Hulme, The University of Auckland Library, 15 Apr. 2006 $<$ http://www.library.auckland.ac.nz/subjects/nzp/nzlit2/authors_az.htm >.

${ }^{214}$ Keri Hulme, Te Kaihau/The Windeater (Wellington: Victoria University Press, 1986).
} 
in 1986), with more than twice this amount ${ }^{215}$ of reviews, it appears quite clear that a genre preference/prejudice is operating. On turning to the bone people however, it is interesting to note that forty-five book reviews of the bone people were published in the short period from 1984-88 216 ; more than fifty-five books/chapters/articles have discussed the novel ${ }^{217}$; and at least thirteen theses have been directly written about $\mathrm{it}^{218}$. Although the bone people's prize-winning status and resultant marketing make this an unbalanced comparison ${ }^{219}$, for the purpose of perspective it is useful to compare the reviews and articles relating to it, with the reviews for Hulme's poetry. While the sheer number of examinations of the novel soon become overwhelming for the researcher, it remains much harder to find in-depth analysis of Hulme's poetry, beyond that found in the initial book reviews. The result of this is that I, as with many of the other reviewers/critics of Hulme's poetry, found myself relying quite heavily on debates and topics raised in relation to the bone people, rather than those brought up by the poetry itself. ${ }^{220}$

A further interesting debate in relation to genre is that surrounding the volume Lost Possessions. In this chapter I have already referred to this title as poetry, as I contend

\footnotetext{
${ }^{215}$ New Zealand Literature File: Keri Hulme, The University of Auckland Library, 15 Apr. 2006 $<$ http://www.library.auckland.ac.nz/subjects/nzp/nzlit2/authors_az.htm $>$.

${ }^{216}$ Gale Research Company, Book Review Index (Detroit: Gale Research Company, 1965- ).; New Zealand Literature File: Keri Hulme, The University of Auckland Library, 15 Apr. 2006 $<$ http://www.library.auckland.ac.nz/subjects/nzp/nzlit2/authors_az.htm >.

${ }^{217}$ New Zealand Literature File: Keri Hulme, The University of Auckland Library, 15 Apr. 2006 $<$ http://www.library.auckland.ac.nz/subjects/nzp/nzlit2/authors_az.htm >.

${ }^{218}$ National Bibliographic Database, The National Library of New Zealand Te Puna Matauranga o Aotearoa, 30 Nov. $2005<$ http://helicon.vuw.ac.nz:3976/cgi-bin/Pwebrecon.cgi>.

${ }^{219}$ The Bone People won both the Pegasus Award for Maori fiction and the Booker Prize. As the recipient of such high-profile awards, the novel was obviously subject to a much more wide-ranging (in terms of both geography and market type) prolonged, and presumably expensive marketing campaign than most other non-prizewinning New Zealand novels.

${ }^{220}$ For example, the well known authenticity debate has been a significant part of the bone people criticism, but only featured in criticism of Hulme's poetry published after 1984 (ie. post-bone people).
} 
that it fulfils the most common definitions of free verse ${ }^{221}$, with each line break standing out as significant rather than accidental, and each 'journal-entry' able to be appreciated as a piece of writing in isolation from the rest. Very few of this book's reviewers agree with me, however. Ian Sharp begins to approach it as poetry, but then emphatically states that it is a work of short fiction (although he does acknowledge that, really, it defies definition.). ${ }^{222}$ Chris Price is less emphatic, but concludes that it “...sags toward prose" ${ }^{223}$ and Janet Wilson agrees. ${ }^{224}$ In his Listener review, Wedde somewhat non-commitally refers to it as a narrative ${ }^{225}$, but then in the Wellington City Magazine he refers to it as "almost verse", "experimental literature" and a “novella-poem". ${ }^{226}$ These indecisive statements encapsulate not only many reviewers' difficulty with this particular volume and the terms on which they are willing to engage with the work, but also with 'pinning-down' the nature of Hulme's writing generally. I would like to suggest that a Mana Wahine Maori approach to Hulme's work would embrace this uncertainty as evidence of her texts' positive multiplicities, and will illustrate this assertion later in this chapter. Koro Dewes, although not evincing a Mana Wahine Maori viewpoint, nevertheless provides context for a tradition of Maori poetry that does not fit contemporary norms regarding poetry: "The tradition in poetry in Maori society is far richer that that of prose. Poetry is sung, intoned, chanted, recited and shouted...,227 This approach is supported by Judylyn S.

\footnotetext{
${ }^{221}$ See the entry for "free verse" in M.H. Abrams' A Glossary of Literary Terms, Harcourt Brace College Publishers, Fort Worth, 1993: "it is printed in short lines instead of with the continuity of prose, but it differs from such verse by the fact that its rhythmic pattern is not organized into metre." Pg 73.

${ }^{222}$ Ian Sarp, rev. of Lost Possessions, by Keri Hulme, New Outlook 19 (Nov.-Dec. 1983): 62.

${ }^{223}$ Chris Price, rev. of Strands, by Keri Hulme, Landfall 46 (Sept. 1992): 371.

224 Janet Wilson, “Hulme's maturing talent," rev. of Strands, by Keri Hulme, Evening Post (13 Mar. 1992) 5 .

${ }^{225}$ Ian Wedde, "Trying to make sense," rev. of Lost Possessions, by Keri Hulme, and Te Kaihau/The Windeater by Keri Hulme, Listener (31 May 1986) 35.

${ }^{226}$ Ian Wedde, rev. of Lost Possessions, by Keri Hulme, Wellington City Magazine (April 1986) 74-5.

${ }^{227}$ Koro Dewes, Maori Literature: a tentative framework for study (Wellington: Victoria University of Wellington, 1974) 7.
} 
Ryan in her examination of Black women's literature: “Applying the ethos of interconnectedness, Black women artists facilitate the varied expressions of multiple genres...within a single work." ${ }^{, 22}$ Haunani-Kay Trask sees this multiplicitious, multigeneric approach as innately political, and thus evidenced in all native Hawaiian, and even in most Native writing worldwide:

... we don't perceive the world of creative writing as divided into categories of prose and poetry or fiction and non-fiction. Nor do we imagine ourselves crossing from political resistance into artistic creation and then back. ${ }^{229}$

Viewing Hulme's poetry, and Lost Possessions in particular from this standpoint is an acknowledgement of their sophistication, of the very conscious decisions behind their construction. I would suggest that seeing them as only some sort of indecisive hybrid form is more indicative of the critics' difficulties in engaging with the work than of anything else.

Before performing any readings of Hulme's poetry, I think it is useful to first look at some more of the previous criticism on it, in order to support my contention that there are spaces in these perspectives that a Mana Wahine Maori approach enables readings of. Firstly then is a claim common to many of the reviewers, but perhaps most succinctly encapsulated by Roger Oppenheim, regarding Maori words in Hulme's poetry: "They hang on the poems like banners proclaiming the Maoriness of the writer, but they rarely create a conceptualization not available in English". ${ }^{230}$ The issue here is perhaps not so much of 'authenticity' along the lines promoted by C.K.

\footnotetext{
${ }^{228}$ Ryan, 39.

${ }^{229}$ Trask, 51.

${ }^{230}$ Roger Oppenheim, "Internal Exile: Continuity and Community in Maori Poetry," rev. of The Silences Between (Moeraki Conversations), by Keri Hulme, and Into the World of Light, eds. Witi Ihimaera and D.S. Long, and Maori Poetry: An Introductory Anthology, ed. Margaret Orbell, and Selected Poems, by Hone Tuwhare, and Karanga, by Haare Williams, Journal of the Polynesian Society 92 (June 1983): 253.
} 
Stead $^{231}$, but more about the apparently self-conscious use of Maori language in her poetry. Chris Price sees "little linguistic self-awareness" in Hulme's use of Maori ${ }^{232}$; Bernard Gadd refers to it as merely a "verbal flourish"233; Peter Alcock refers to her poetry's "Maori savour" ${ }^{, 234}$ while Peter Marks hail its "exotic mixture". ${ }^{235}$ As with the claims surrounding the genre of Lost Possessions, these statements say far more about the reviewer's background than about the poetry itself. In fact, apart from Anne French, I believe that all of the reviewers of Hulme's poetry have been Pakeha, and the lack of a Maori counter-balancing view does seem to have led them to all approach the text from more or less the same angle. The discussion that I am framing around Hulme's work will not be rating its 'Maori-ness' on a scale of one to ten and using this to pronounce on the success of the poetry. Not only do I find this to be a pointless, unfruitful approach, but I have personally found it very difficult to differentiate between Maori that is mainly used as a flavouring in Hulme's work and Maori that is an essential ingredient, and would certainly be loathe to pronounce that Hulme needs just a little more horopito in order to give her poetry the correct amount of spice. $^{236}$

A further trend in criticism of Hulme's poetry is to slap it with a backhanded compliment akin to "strong ... but simple." For example, Elizabeth Crayford writes of the collection The Silences Between: Moeraki Conversations, that it "...finds release

\footnotetext{
${ }^{231}$ Stead, C.K. "Keri Hulme's The bone people and the Pegasus Award for Maori literature.” Ariel 16.4 (Oct. 1985): 101-108.

232 Price 370.

${ }^{233}$ Bernard Gadd, "World Literature in Review: New Zealand," rev. of Strands, by Keri Hulme, World Literature Today 67.2 (Spring 1993): 452.

${ }^{234}$ Peter Alcock, rev. of The Silences Between (Moeraki Conversations), by Keri Hulme, Landfall 37 (June 1983): 212.

${ }^{235}$ Peter Marks, rev. of Strands, by Keri Hulme, British Review of New Zealand Studies 6 (Nov. 1993): 139.

${ }^{236}$ I know that if my mother ever suspected that I was being arrogant enough to criticise the seasoning in someone else's cooking (ie. hers), she would give me a whack and tell me "you get what you're given or you can go and make your own!"
} 
not in tortuous soul-searching and tedious confession, but through a strong identification with the land and its history." ${ }^{, 237}$ Meg Campbell agrees with such an assessment when she writes of the same volume: "She puts up no artificial barriers between her poems and the reader; there is no coyness or mystification."238. Chris Price is even more emphatic regarding the collection Strands: “...there is little of the linguistic self-awareness the epigraph anticipates". ${ }^{239}$ As will be evidenced later in this chapter, such comments are very close to patronizing, and are not only simplistic themselves, but show an ignorance of the complexity of such poems as "Fishing the Olearia Tree" in Strands: yes, it is possible to read this poem as a nicely observed naturalistic snapshot of a swamp. However, there are many different creatures lurking inside that swamp, including observations on colonisation, patriarchy and Maori culture, amongst many other factors. At least one reviewer acknowledged mistrust of the seemingly calm surface of Hulme's poems though: "These lines made me relax, enjoy the textures and colours of the book without worrying myself silly over misinterpretation. It seems they deserve much more. Stark clarity quickly seemed like lead poisoning." ${ }^{240}$ The real problem is that this strong/simple dichotomy reaches beyond criticism of Keri Hulme's poetry. As illustrated in Chapter Two, Roma Potiki's poetry has also been labeled in this way. And Konai Helu Thaman has noted that such unawareness extends right across Oceania: "Sometimes when I read reviews of books by Pacific authors, I am struck by the obvious lack of understanding or the work in relation to the context in which it is written." ${ }^{241}$ It is very probable that this is

\footnotetext{
${ }^{237}$ Elizabeth Crayford, "Mystery and Muddle," rev. of The Silences Between (Moeraki Conversations), by Keri Hulme, and Mystical Choice: 47 Poems by New Zealand Poets, sel. Helen Shaw, The CRNLE Reviews Journal 1 (July 1983): 21.

${ }^{238}$ Meg Campbell, "Spirit World," rev. of The Silences Between (Moeraki Conversations), by Keri Hulme, Listener 11 Sept. 1982: 110.

${ }^{239}$ Price 370

${ }^{240}$ Greg Treadwell, rev. of Strands, by Keri Hulme, Stamp 31 (1992): 30.

241 Thaman 42.
} 
a complaint common to many reviews of the literature from people of colour, including Indigenous literature: if one does not comprehend the culture from which a text emerges, then how do they expect that they will recognise that culture in the text?

The lack of understanding of the culture a text is centred in is directly related to the attempt, by many reviewers of Hulme, to assign familiarity to her poetic texts by an over-reliance on the reviewer's own cultural referents. The result of this is a roll call of historical English (mainly) literature as the reviewer attempts to describe just what sort of poetry this is. Firstly then, is Chris Price's analysis of Hulme's poetry as reminiscent of Yeats, Blake, the Bible and Lao-tzu: "All this constitutes very powerful cultural baggage". ${ }^{242}$ Yes, but whose baggage, exactly? Next, Janet Wilson hears "Biblical echoes”, Shakespeare, Blake, Keats, and TS Eliot in Hulme's work. ${ }^{243}$ Anne French also sees Blake and Shakespeare in Hulme, but then throws Thoreau into the mix. ${ }^{244}$ Bruce Harding restricts his list to merely Lewis Carroll and Coleridge ${ }^{245}$, while Alistair Paterson not only pulls Whitman in, but thanks Yeats for the emotion and philosophy in Hulme's poetry: "The rest (except for her more recent reading of Blake) is Hulme herself..."246 Perhaps "rest" here refers to the typographical decisions, as there doesn't seem to be much else left. Finally, Peter Alcock mentions the inspiration of Melville, DH Lawrence and Yeats on "...that Whitmanesque taniwha Keri herself". Perhaps if he'd followed up with a reading of Roma Potiki's poetry, he might have been less willing to so blithely call a taniwha into his review. What all of these reviews have in common is the devotion of much space to naming

\footnotetext{
242 Price 370.

${ }^{243}$ Wilson 5.

${ }^{244}$ Anne French, rev. of Strands, by Keri Hulme, Dominion 28 Mar 1992: 11.

${ }^{245}$ Bruce Harding, "Dream-Catcher," rev. of Strands, by Keri Hulme, Listener 1 June 1992: 52-54.

${ }^{246}$ Alastair Paterson, "The discourse of security," rev. of Red Letter, by Janet Charman, and Strands, by Keri Hulme, New Zealand Books: A Quarterly Review 3.1.9 (Winter 1993): 8.
} 
but none, or very little to explaining or illustrating Keri Hulme's 'influences', either of which would provide much more backbone to such conveniently ${ }^{247}$ simple claims. Again, such claims of influence go wider than Hulme's writing, Mana Wahine Maori writing in English, or even Indigenous writing in English. In an interview Toni Morrison showed that she had had enough of such lazy, and often very mistaken comparisons to dead white men: "I am not like James Joyce; I am not like Thomas Hardy; I am not like Faulkner" ${ }^{248}$ Such comparisons deny the writer, such as Hulme, individuality, originality and the even possibility of cultural influences that are far stronger than those of a typical Eurocentric 'canonical' reading list.

Having critiqued these aspects of previous readings of Hulme's work, the rest of this chapter attempts to read her work in a different way. That is, in a way that acknowledges Hulme's identity as a Maori woman, as thus her poetry as being the poetry of a Maori woman. I will illustrate how this approach is able to read the 'difficulties' in her work as the complex multiplicities that they really are. To this end, I will be using Mana Wahine Maori to frame this discussion. Not only can Mana Wahine Maori critical theory be used with utility to discuss Keri Hulme's work, but terming her poetry an example of Mana Wahine Maori poetry in English allows recognition of the importance of factors such as whenua, iwi and cultural identity in the work to be brought to the fore. This emphasizes that these are not merely elements of the poems - they are much more sustained and integral factors. An example of this can be seen in the following section from the long poem "Fishing the Olearia Tree":

Feel the mud under your toes. Feel this deep warm inviting mud - no shells or sharp things to harm your skin - just a

\footnotetext{
${ }^{247}$ These illustrious surnames fit quite neatly into a 200 word book review, yet carry with them a grand weight of association.

${ }^{248}$ Ryan, Spirituality as Ideology in Black Women's Film and Literature 99.
} 
squelching friendly mud. Just an easeful welcoming mud.

Protective mud. In the beginning there was mud. In this

end, mud. ${ }^{249}$

The multiple repetition of the word "mud", made even more prominent when it is read aloud, signals that there is more going on in this stanza than might initially seem the case. The first woman, Hineahuone, was shaped out of dirt - "In the beginning there was mud". Toitu he whenua, whatungarongaro he tangata - the land remains, though man disappears: "In this end, mud". Papatuanuku is the earth mother: "Protective mud". The land appears in almost every poem, and it is hardly ever silent.

Connected to the land are the people: in "Silence... Overseas" -

I am going away, for weeks away, from my family, my land, my bones... ${ }^{250}$

Family, land and bones are offered here as synonyms; different words in English, but in Maori they might almost be inter-changeable/interrelated/interlinked terms, whanau, hapu, iwi. So in "Silence...on another marae", when one speaker asks:

Where are your bones?

the answer is:

\section{Whisper:}

Moeraki: Purakanui: Arahura:

\section{Okarito: Murihiku: Rakiura... ${ }^{251}$}

These chanted names reappear in other poems, fastening them to the landscape of the poetry. These names are the bones - not only of physical locations, but of long-dead

\footnotetext{
${ }^{249}$ Hulme, "Fishing the Olearia Tree," Strands 20.

${ }^{250}$ Hulme, "Silence... Overseas," The Silences Between 32(3-4).

${ }^{251}$ Hulme, Keri, The Silences Between (Moeraki Conversations) 25-6(9-12).
} 
tupuna and living whanau, of marae and of whare. ${ }^{252}$ The phrase "bleached of my identity" 253 occurs in the poem "Rua tekau ma tahi", part of the section "Silence... Overseas". This might not only be a reference to pale-skin colour, but also to bones, which, stripped of the land and people to which they belong, are also bleached of their context, as thus, their identity. And, of course, there is an obvious connection to the bone people and all of talk of family, land and personal skeletons contained therein.

\section{$\underline{\text { Much-tongued, still potent: }}$}

This is, of course, a reference to the section of the poem "Fishing the Olearia Tree", published in the 1992 collection Strands: "even much-tongued things are very faintly potent, like old old ambergris." 254 In the face of twenty years of reviews, academic articles, theses and conference papers the bone people has maintained its potency, and remains at the centre of many furious debates, including those focused on issues of violence, race, culture, authenticity and national identity. I will now turn to a short discussion of the novel, before proceeding with the argument - raised briefly in Chapter One in relation to the work of Roma Potiki - that one of the advantageous features of the grouping "Mana Wahine Maori Poetry in English" is that it encourages a reading of an author's work across her entire oeuvre, thus raising the potential of expanding the grouping to "Mana Wahine Maori Writing in English".

\footnotetext{
${ }^{252}$ Roma Potiki puts it thus: "Our bones fashioned / from floating history anchor firmly to the land." Potiki, "Waiuu," Oriori 66(10-11).

${ }^{253}$ Hulme, "Rua tekau ma tahi," The Silences Between 40(5).

${ }^{254}$ Hulme, "Fishing the Olearia Tree," Strands 17.
} 
What has been missing from the majority of the debates surrounding the bone people is a consideration of this as a Maori novel, using Mana Wahine Maori critical theory to frame the discussion. Very few of the previous approaches to the book have really centred Mana Wahine Maori. In fact, a review of the articles written about the bone people, as with those written about Hulme's poetry, illustrates a clear preference for feminist, postcolonial and modernist and postmodernist literary approaches. For example, in her 2004 text The Circle and the Spiral, Eva Rask Knudsen ${ }^{255}$ writes of the bone people as: “... a literary exemplar of how a story can grow from a Maori mould into a postcolonial novel". ${ }^{256}$ The word "grow" here suggests a blossoming, from the seed of something important into a mature understanding. This sense of progression, also discussed in many other postcolonial reviews of her novel denies Hulme's agency in the process, and implies that the "Maori mould" is not a mature one; that it is merely a starting point, as if being read as 'Maori novel' would constrain it. Where such a view can be problematic is seen is the following sentence, where Knudsen talks about the structures that the character Simon constructs on the beach: “...Simon's music hutches are built in the ambivalent wasteland between land and sea.",257 As the 2004 "Seabed and Foreshore" march on Parliament by tens of thousands of mainly Maori protestors showed however, those particular geographic locations are not considered "wasteland" by everyone; and, indeed, are a vitally important source of kaimoana. ${ }^{258}$

\footnotetext{
${ }^{255}$ I refer to only Knudsen's work here, as it is the most recent academic book to focus on the bone people, and yet it contains many of the same problematic assumptions and assertions that have featured in most of the books published in the twenty years prior to it. For example, it attempts to gauge the effectiveness of Hulme's use of Maori symbols, often by reference only to late nineteeth century/early twentieth century Pakeha ethnographic work. Eva Rask Knudsen, The Circle and the Spiral: a study of Australian aboriginal and New Zealand Maori literature, (Amsterdam; New York: Rodopi, 2004).

${ }^{256}$ Knudsen 129.

${ }^{257}$ Knudsen 158.

${ }^{258}$ From a Pakeha perspective, the small strip of sand between the more obvious actors of land and sea is merely a place to put an umbrella and towel, ride a horse or motorbike, or go for a run. These activities can all be carried out in other places, and do not rely on the foreshore for their existence.
} 
I certainly acknowledge that these other approaches have performed important work in opening up many elements of this novel for discussion. However, and as was the case with Roma Potiki's poetry, such approaches do run the real risk of marginalisation: "Kerewin's ailment is intrinsic to a cultural schizophrenia caused by colonialism which Abdul Jan Mohamed, inspired by Franz Fanon, has termed "the

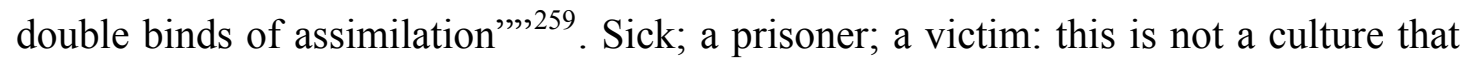
can be allowed control of itself. However, such marginalisation will not be tolerated for long, and indeed, the poetry itself aims to wrest that control back. In "A Deal Among the Makyrs" the speaker rails at the injustices committed by "The gods of Literature o".260 " - or hurl them to far peaks / knowing that icicles and silence result “261 The speaker's words have been placed on a pedestal so unassailable that they are eventually ignored: they can no longer breathe in such refined air. That this is a reference to the bone people seems quite clear, and is supported by a further reference: "battered soiled cards are flopped down on a bone pile". ${ }^{262}$ And, in an earlier line, we are told: "The cards are strange and flattened people". ${ }^{263}$ This is a protest that, rather than having opened that novel out for interpretation, the potentially reductive qualities of literary criticism have instead been realised.

As the aim of this thesis is to focus on poetry, rather than other literary genres, I will not be engaging in a deep discussion of this novel here. However, there are important

\footnotetext{
Gathering shellfish and land fishing however, an important and free source of daily nutrition both traditionally and in contemporary times, can only be carried out in this arena. This small strip then is and was tremendously important to sustaining life.

${ }^{259}$ Knudsen 148.

${ }^{260}$ Keri Hulme, Stonefish (Huia Publishers: Wellington, 2004) 22-3(1).

${ }^{261}$ Hulme, Stonefish 22-3(7-8).

${ }^{262}$ Hulme, Stonefish 22-3(20).

${ }^{263}$ Hulme, Stonefish 22-3(12).
} 
intersections between the novel, the poetry and the theory that throw up some interesting new perspectives on each $^{264}$. So how then does a reading of Hulme's poetry, informed by Mana Wahine Maori critical theory, open up new ways of looking at the bone people? Although the critic Bernard Gadd saw connections between the novel and the poetry, specifically Strands, he remained unconvinced that this was intentional: “...but I think these are more the result of the similarities of the source materials than a deliberate literary playfulness". ${ }^{265}$ However, a closer reading than this would seem to provide ample evidence of such deliberate intertextuality. An example of this can be seen in the poem "He moemoea". ${ }^{266}$ This features a named 'Simon', described dancing on a beach, golden and smiling. However, this halcyon depiction is soon replaced by a general air of sadness. Read by themselves, the lines:

the small man

keeps on weeping/O

how can I keep you here ${ }^{267}$

and the repetition of the word "love" might suggest the ending of a love affair. Read in conjunction with the bone people however, the statement is more ominously suggestive of imprisonment; suddenly, the bleeding wine droplet brings to mind a possible Christian sacrifice, while the mention of glass reminds the reader of the shattered bottle embedded in Binny Daniel and the sliver that cut into Joe's stomach. It is not necessary to read this as a conclusive link between the works: as some sort of prologue, or ultimate epilogue. What it affords instead is a reminder of the reader's

\footnotetext{
${ }^{264}$ I am aware that although I talk of the advantages of looking across an author's entire body of work, I do not address Hulme's short stories, to be found in The Windeater/Te Kaihau, Stonefish, etc. I acknowledge that in order to more fully prove my contention, such an investigation would be useful. However, due to restrictions of space and a desire to keep the majority of this thesis focused on the work of Roma Potiki, I will not cover these works here.

${ }^{265}$ Gadd 452.

${ }^{266}$ Hulme, "He moemoea," The Silences Between (Moeraki Conversations) 14.

${ }^{267}$ Hulme, "He moemoea," 14(25-27).
} 
implication in the acceptance of violence in the bone people. "But I knew all along, Herr Gott. Something always felt wrong." Something feels wrong in the poem too, but in lieu of an explicit statement of violence, the reader is willing to overlook it. In their article, Pihama, Cram and Walker highlight the need to emphasize the "collective responsibility of the Maori community and whanau to address issues of socioeconomic disadvantage and the negative pressures [such as violence]". Acknowledging collective responsibility in addressing such issues then, is a site at which the poetry, the novel and the critical theory meet.

There are also important references to bones that figure in the novel and may also be seen in the poetry too. This returns to the earlier argument that one of the useful features of this grouping is that it encourages a reading of an author's work across her entire oeuvre. In Keri Hulme's case, reading the bone people in conjunction with her poetry may indeed suggest intriguing new possibilities for interpretation. When I began using Mana Wahine Maori critical theory to read Hulme's poetry, I felt that not only did open up new ways of looking at single poems, or even an entire collection: it also suggested the possibility of making connections across her work as a whole. It was this interaction between the critical framework and the texts that suggested the grouping 'Mana Wahine Maori Writing in English': that is, writing that evinces Mana Wahine Maori principles throughout all of an author's writing. This ability to discuss an author's work as a whole allows a different set of questions to be asked of it, which can be illustrated by reference to the difficulty that a number of reviewers had with the section of Strands entitled "Some Wine Songs". Bernard Gadd, for example, in World Literature in Review: New Zealand, says of this section that it is 
“...considerably lighter and indeed so far out of kilter with the major poetry as to suggest that the publishers wanted to bulk up the collection" ${ }^{268} \ldots$

Cultural identity is also an issue portrayed in both the poetry and the novel. In the bone people, there is an exchange between Kerewin and Joe after they have just met, where they discuss their ethnicity: "By heart, spirit and inclination I feel all Maori. Or...I used to. Now, it feels like the best part of me has got lost in the way I live.” The poem "Silence... on another Marae" extends the reasons for this insecurity beyond lifestyle, to physical appearance:

to me, pale and bluegrey-eyed, skin like a ghost, eyes like stones; to me, always the manuhiri when away from homethe weeping rings louder than the greeting. ${ }^{269}$

While pale skin colour is also an element in the bone people's portrayal of culture and identity, the additional reference in the poem to being away from home is an important one. What it suggests is that Kerewin's alienation from her family, the physical proof of her whakapapa, is a major reason for the loss of confidence in her Maori identity. A question that might be raised here is that if some of the major speakers in the poems and novel do not feel completely comfortable identifying as Maori, then how is it possible to identify the works as such - that is, as Mana Wahine Maori writing? I will contend that this acknowledgement of an insecurity of cultural

\footnotetext{
${ }^{268}$ Gadd 452. There are important implications and limitations to performing this type of reading that centres Mana Wahine Maori: for example, the Celtic features that appear in both Hulme's poetry and the bone people have remained undiscussed in this thesis. In his review of Strands, Bruce Harding makes reference to the appearance in one section of "the three Celtic sister-goddesses, who contemplate the creation and destruction of worlds". Keri Hulme is also of Celtic descent, so clearly the same type of reading that I have been performing for her Maori work could be performed for her work's Celtic features. However, every project must have its parameters, particularly a 30, 000 word thesis, and so I happily leave this particular investigation to others.

${ }^{269}$ Hulme, "Silence... on another Marae," The Silences Between 25-26(30-33).
} 
identity, rather than undermining this as a Maori novel, is actually one of the factors that mark it out as such. As previously illustrated, this can also be seen in Roma Potiki's poetry: "She's like a fast American, / English street-kid in Puerto Rico". 270 There might be a number and great variety of cultural influences that make up one's identity, and which also seem to threaten, at times, to subsume it. However, in the end this may owe more to the onlooker's perception, than the reality:

And when she smiles

you remember...

She isn't a

deep south blues mama,

she's your cousin from Lower Hutt,

remember. $^{271}$

Personality and identity can obviously be sustained from more than one source, otherwise how would we bi/multicultural descendents be able to reconcile our existence? However, this does not mean that our identities are not occasionally problematic to ourselves as well though.

I also think that it is possible that this intertextual approach may have been presaged by Hulme's work itself decades ago. For example, the phrase "co-eye, kor-fie, alla same tree", which appears in the poem "Moeraki Conversations: 1" also directly appears in the bone people with the added smiling question "geddit?" And it is definitely possible that the work may have actively suggested such a direction as this: in "Fishing the Olearia Tree" -

\footnotetext{
${ }^{270}$ Potiki, "Big Susanah," Shaking the Tree 14(10-11).

${ }^{271}$ Potiki, "Big Susanah," 14 (17-23).
} 
there are needles enough

shuttling backwards and forth

making the pattern

that is also the teacher ${ }^{272}$

Hulme's own writings clearly contain the needles that bind and weave together her work, so perhaps it is to be expected that I finish by saying that the dialogue created by the interaction between Mana Wahine Maori critical theory, Keri Hulme's poetry and the bone people not only provides rich and multilayered insights into all three of these areas, but also actively produces a grouping of literature, one that I have called here 'Mana Wahine Maori Writing in English”.

${ }^{272}$ Hulme, "Fishing the Olearia Tree," Strands 19. 


\section{DRINK ENOUGH BLOOD /}

TO GATHER STRENGTH...

Returning now to Roma Potiki and the main contention of this thesis, the naming of Potiki's poetry as an example of Mana Wahine Maori poetry in English is the most positive and constructive way to admit and debate the multiplicities inherent not only in her writings, but in the critical writings that have been held in this thesis to express and explore ideas of Mana Wahine Maori. The implications of naming this grouping 'Mana Wahine Maori poetry in English' have been acknowledged: rather than establishing either an unproductive canonicity of the texts in this grouping, or creating a template of how to read Mana Wahine Maori poetry in English, this thesis has instead indicated some of the ways in which the intersections between these creative and critical writings could be read.

In exploring the potentialities of Mana Wahine Maori poetry in English, this thesis also addressed the challenge laid down in Roma Potiki's poem "The Decision of the Taniwha": that is, to centre the experience of Maori, and in particular wahine Maori. This was achieved by illustrating the utility of the name 'Mana Wahine Maori poetry in English' and all of the various denotations and connotations of such a name. It was shown that the significance of mana in Maori society differentiated this name from 'Maori feminist poetry in English'. That is, 'Mana Wahine Maori poetry in English' is not just the of use Maori terminology in preference to English, but rather enables an approach to the texts that celebrates and holds the experience of wahine Maori at its centre. Following this it was shown, by reference to the traditional and contemporary power and knowledge of wahine Maori, that we have always been at the centre of our own definitions of wahine Maori experience. Additionally, Black American, Native 
American, First Nations, Australian Aboriginal and Pasifika women's experiences in pursuing their own literary and linguistic self-determination were explored. This illustrated that there are many commonalities between our experiences and thus there are also many useful ways in which their various forms of theorizing provoke important questions for Mana Wahine Maori, and by extension, the grouping Mana Wahine Maori Poetry in English. However, this was not an attempt to integrate all of these variant experiences into one 'meta-Indigenous-Feminist critical theory'. Due to our different social, cultural and political contexts, there are some very important limitations in the extent to which contentions made by Black American, American, First Nations, Australian Aboriginal and Pasifika feminist literary critical methodologies can be applied in Mana Wahine Maori. The focus was then returned to the social, cultural and political milieu of 'Mana Wahine Maori'. By specific reference to Iwi/Hapu/Whanau contexts, urban wahine Maori contexts and wahine takatapui contexts, it was shown that there are indeed many different intersections at which wahine Maori creative and critical writing meet. That there are intersections confirmed the pluralistic and flexible nature of Mana Wahine Maori poetry in English: this grouping is not a closed box of knowable limitations. Finally, it was also shown that Mana Wahine Maori poetry in English is still a productive grouping when extended beyond the reading of Roma Potiki's poetry. Examining the poetry of Keri Hulme, it was shown that a reading of her work as Mana Wahine Maori poetry in English was just as appropriate, and as useful. Furthermore, by reference to Hulme's novel the bone people, it was demonstrated that that there is a valid argument to extending this grouping to Mana Wahine Maori writing in English, as there are a multitude of complex and interesting intersections between all of these works that enables multidimensional readings here too. 
At the beginning of Chapter Five I commented that a deep examination of the work of every Maori woman poet in conjunction with this grouping was a task that was outside of the scope of a short Masters thesis. I acknowledge that there are others doing very valuable research in this area, but even a quick summary of the theses, articles and books on this topic shows that the critical output, including my own, is far from having examined all of the artistic output of Maori women poets.

The rest will dance a slow dance

in the light of her scales,

drink enough blood

to gather strength for the real work. ${ }^{273}$

It is to be hoped that the final stanza of Potiki's "The Decision of the Taniwha" will be taken as an exhortation to others to join in the dance, gather strength in numbers, and keep doing more of this vital work.

${ }^{273}$ Potiki, "The Decision of the Taniwha" 52-3 (35-8). 


\section{BIBLIOGRAPHY}

Abrams, M.H. A Glossary of Literary Terms. Fort Worth: Harcourt Grace College Publishers, 1993..

Alcock, Peter. Rev. of The Silences Between (Moeraki Conversations), by Keri Hulme. Landfall 37 (June 1983): 209-13.

Allan, Guy. "Poets keeping words sacred". Rev. of Stone Rain, by Alistair Campbell, and Rerenga, by Trixie Te Arama Menzies, and Pakake! Pakake!, by Toi Te Rito Maihi, and Stones in Her Mouth, by Roma Potiki. New Zealand Herald 18 July 1992: 2.6.

Allen, Chadwick. Blood Narrative: Indigenous Identity in American Indian and Maori Literary and Activist Texts. Durham and London: Duke University Press, 2002.

Allen, Paula Gunn. The Sacred Hoop: Recovering the Feminine in American Indian Traditions. Boston: Beacon Press, 1986.

Awatere, Donna. Maori Sovereignty. Auckland: Broadsheet, 1984.

Baker, Emerance. "Loving Indianess: Native Women's Storytelling as Survivance." Atlantis 29.2 (Spring 2005): 111-122.

Battista, Jon. "Nga Ahorangi." Hecate 23.1 (May 1997): 143-77.

Beatson, Peter. The Healing Tongue: Themes in Contemporary Maori Literature. Palmerston North: Sociology Dept. Massey University: 1989.

Bishop, Russell. "Freeing ourselves from neo-colonial domination in research: An indigenous approach to creating knowledge." Association for Research in Education, Massey University (1995): 3-35.

Gale Research Company. Book Review Index. Detroit: Gale Research Company, 1965-

Campbell, Meg. "Spirit World." Rev. of The Silences Between (Moeraki Conversations), by Keri Hulme. Listener 11 Sept. 1982: 110.

Courses and Subjects: English. Canterbury University. 15 Apr. 2006

$<$ http://www.canterbury.ac.nz/courseinfo/GetCourses.aspx?type=course\&value $=$ engl\&source $=$ courses $>$.

Clarke, Eileen. "The Taniwha's exile: the exclusion of Maori women from environmental policy and decision-making in Aotearoa/New Zealand." Hecate 30.1 (May 2004): 119-140. 
Crayford, Elizabeth. "Mystery and Muddle." Rev. of The Silences Between (Moeraki Conversations), by Keri Hulme, and Mystical Choice: 47 Poems by New Zealand Poets, sel. Helen Shaw. The CRNLE Reviews Journal 1 (July 1983): 21-3.

Dewes, Koro. Maori Literature: a tentative framework for study. Wellington: Victoria University of Wellington, 1974.

Durie, Mason. Te Mana, Te Kawanatanga: The Politics of Maori Self-Determination. Auckland: Oxford University Press, 1998.

Eggleton, David. "Poems from the inside out." Rev. of Shaking the Tree, by Roma Potiki. Evening Post 22 May 1998: 5.

English: Faculty of Arts. University of Auckland. 15 Apr. 2006

$<$ http://www.arts.auckland.ac.nz/subjects/index.cfm?P=1738>.

English, Film, Theatre, Media Studies. Victoria University of Wellington. 15 Apr. $2006<$ http://www.vuw.ac.nz/seft/english/courses/index.aspx\#a400>.

French., Anne. Rev. of Strands, by Keri Hulme. Dominion 28 Mar 1992: 11.

Gadd, Bernard. "World Literature in Review: New Zealand." Rev. of Strands, by Keri Hulme. World Literature Today 67.2 (Spring 1993): 452.

Gates, Henry Louis, Jr. Loose Canons: Notes on the Culture Wars. Oxford: Oxford University Press, 1992.

Gibaldi, Joseph. MLA Style Manual and Guide to Scholarly Publishing. New York: The Modern Language Association of America, 1998.

Graham, Bella Te Aku. "Riding Someone Else's Waka: Academic Theory and Tribal Identity." Meridian : the La Trobe University English Review (1995): 45-63.

Gregory, Derek. Geographical Imaginations. Cambridge MA: Blackwell, 1994.

Harding, Bruce. "Dream-Catcher." Rev. of Strands, by Keri Hulme. Listener 1 June 1992: 52-54.

Harris, Aroha. "Poems challenge." Rev. of Stones in Her Mouth, by Roma Potiki. Evening Post 14 Aug 1992: 5.

Heiss, Anita M. Dhuuluu-Yala To Talk Straight: Publishing Indigenous Literature. Canberra: Aboriginal Studies Press, 2003.

Henry, Ella and Hone Pene. "Kaupapa Maori: Locating Indigenous Ontology, Epistemology and Methodology in the Academy." Organization: Speaking Out 8.2 (2001): 234-42. 
Henry, Ella Y. "Rangatira Wahine: Maori Women Managers \& Leadership." Thesis. University of Auckland, 1994.

hooks, bell. Ain't I a Woman: Black Women and Feminism. Boston MA: South End Press, 1981.

Hoskins, Te Kawehau Clea. "In the Interests of Maori Women?: Discourses of Reclamation." Bitter Sweet: Indigenous Women in the Pacific. Eds.Alison Jones, Phyllis Herda and Tamasailau M. Suaalii. Dunedin: University of Otago Press, 2000.

Hulme, Keri. Lost Possessions. Wellington: Victoria University Press, 1985.

---. Te Kaihau/The Windeater. Wellington: Victoria University Press, 1986.

---. the bone people. Auckland: Spiral; Hodder \& Stoughton, 1985.

---. The Silences Between (Moeraki Conversations). Auckland : Auckland University Press; London: Oxford University Press, 1982.

---. Stonefish. Wellington: Huia Publishers, 2004.

---. Strands. Auckland: Auckland University Press, 1992.

Irwin, Kathie. "CChallenges', to Maori Feminists." Broadsheet: Twenty Years of Broadsheet Magazine. Auckland: New Women's Press, 1992. 79-85.

---. From Maori Feminism. Te Ao Marama 2 Regaining Aotearoa: Maori Writers Speak Out. Ed. Witi Ihimaera. Auckland: Reed Publishing, 1993. 299-304.

Irwin, K.G. and W. Katene. Maori People and the Library: A Bibliography of Ngati Kahungunu and Te Waka o Takitimu Resources. Wellington: Victoria University of Wellington, 1989.

Irwin, Kathie. "Maori Research Methods and Practices." Sites 28 (Autumn 1994): 25 43.

Irwin, Kathie. "Towards Theories of Maori Feminisms." Feminist Voices: Women's Studies Texts for Aotearoa/New Zealand. Ed. Rosemary Du Plessis. Auckland: Oxford University Press, 1992. 1-21.

Johnson, Miranda. "Yielding to the Surges." Rev. of Shaking the Tree, by Roma Potiki, and The Paper Road, by Julie Leibrich, and the ordinary magic, ed. Vivienne Plumb. New Zealand Books: A Quarterly Publication 8.4 (Oct. 1998): 17.

Johnston, Patricia Maringi G. "Maori women and the politics of theorizing difference." Feminist Thought in Aotearoa/New Zealand: Differences and Connections. Eds. Rosemary Du Plessis and Lynne Alice. Auckland: Oxford University Press, 1998: 29-36 
King, Thomas. The Truth About Stories: A Native Narrative. Toronto: House of Anansi Press, 2003.

Knudsen, Eva Rask. The Circle and the Spiral:a study of Australian aboriginal and New Zealand Maori literature. Amsterdam; New York: Rodopi, 2004.

Kupenga, Vapi, and Rina Rata and Tuki Nepe. "Whaia te Iti Kahurangi: Maori Women Reclaiming Autonomy." Te Ao Marama 2 Regaining Aotearoa: Maori Writers Speak Out. Ed. Witi Ihimaera. Auckland: Reed, 1993. 304-309.

Marks, Peter. Rev. of Strands, by Keri Hulme. British Review of New Zealand Studies 6 (Nov. 1993): 139-140.

Marsh, Selina Tusitala. "Ancient Banyans, Flying Foxes and White Ginger: The Poetry of Pacific Island Women." Bitter Sweet: Indigenous Women in the Pacific. Eds.Alison Jones, Phyllis Herda and Tamasailau M. Suaalii. Dunedin: University of Otago Press, 2000. $137-159$.

---. "Migrating Feminisms: Maligned Overstayer or Model Citizen?" Women's Studies International Forum. 21.6 (1998): 665-680.

Matahaere-Atariki, Donna. "At the gates of the knowledge factory: voice, authenticity, and the limits of representation." Feminist Thought in Aotearoa/New Zealand: Differences and Connections. Eds. Rosemary Du Plessis and Lynne Alice. Auckland: Oxford University Press, 1998: 68-75.

Mihesuah, Devon Abbott. So You Want to Write about American Indians? A Guide for Writers, Students, and Scholars. Lincoln: University of Nebraska Press, 2005.

Mikaere, Ani. The Balance Destroyed: Consequences for Maori Women of the Colonisation of Tikanga Maori. Thesis. Waikato University, 1995. Auckland: The Institute for Maori and Indigenous Education and Ani Mikaere, 2003.

New Zealand Literature File. The University of Auckland Library. 15 Apr. 2006 $<$ http://www.library.auckland.ac.nz/subjects/nzp/nzlit2/authors_az.htm >.

Olsen, Hope A. The Power To Name: Locating the Limits of Subject Representation in Libraries. Dordrecht: Kluwer Academic Publishers, 2002.

Oppenheim, Roger. "Internal Exile: Continuity and Community in Maori Poetry." Rev. of The Silences Between (Moeraki Conversations), by Keri Hulme, and Into the World of Light, eds. Witi Ihimaera and D.S. Long, and Maori Poetry: An Introductory Anthology, ed. Margaret Orbell, and Selected Poems, by Hone Tuwhare, and Karanga, by Haare Williams. Journal of the Polynesian Society 92 (June 1983): 245-257.

Orbell, Margaret, ed. Contemporary Maori Writing. Wellington: A.H. \& A.W. Reed, 1970. 
Paterson, Alistair. "The discourse of security." Rev. of Red Letter, by Janet Charman, and Strands, by Keri Hulme. New Zealand Books: A Quarterly Review 3.1.9 (Winter 1993): 8.

Pihama, Leonie, Fiona Cram and Sheila Walker. "Creating Methodological Space: A Literature Review of Kaupapa Maori Research". Canadian Journal of Native Education 26.1 (2002): 30-43.

Pihama, Leonie and Patricia Johnston. "The marginalization of Maori women." Hecate 20.2 (Oct. 1994): 83-98.

Pollock, Griselda. Differencing the Canon: Feminist Desire and the Writing of Art's Histories. London and New York: Routledge, 1999.

Potiki, Roma. The Angus Inn Pub Poets III. Ed. Moira Wairama. Petone: Hutt Valley Community Arts Council, 1995: 59-60.

---. "Confirming Identity and Telling the Stories: A Woman's Perspective on Maori Theatre." Feminist Voices: Women's Studies Texts for Aotearoa/New Zealand. Ed. Rosemary Du Plessis. Auckland: Oxford University Press, 1992. 153-162.

Potiki, Roma, and Robyn Kahukiwa. Oriori: a Maori Child is Born: From Conception to Birth. Auckland: Tandem, 1999.

Potiki, Roma. Shaking the Tree. Wellington: Steele Roberts, 1998.

---. Stones in her Mouth. Tamakimakaurau, NZ: IWA, 1992.

---. "He Wahine Kaimahi Whakangahau.” Race, Gender \& Class 9-10 (Dec. 1989): 112-119.

Price, Chris. Rev. of Strands, by Keri Hulme. Landfall 46 (Sept. 1992): 369-372.

Rangihau, John. "Being Maori." Te Ao Hurihuri: The World Moves On. Ed. Michael King. Wellington: Hicks Smith \& Sons, 1975. 221-233.

Rika-Heke, Powhiri Wharemarama. "Margin or Center? "Let me tell you! In the Land of my Ancestors I am the Centre": Indigenous Writing in Aotearoa". English Postcoloniality: Literatures from around the world. Eds. Radhika Mohanram and Gita Rajana. Westport: Greenwood Press, 1996.

Ryan, Judylyn S. Spirituality as Ideology in Black Women's Film and Literature. Charlottesville and London: University of Virginia Press, 2005.

Ryan, P.M. The Reed Dictionary of Modern Maori. Auckland: Reed Books - Reed Publishing, 1995.

Sharp, Iain. Rev. of Lost Possessions, by Keri Hulme. New Outlook 19 (Nov.-Dec. 1983): 62 . 
Shirres, Michael P. Te Tangata: The Human Person. Auckland: Accent Publications: 1997.

Smith, Patricia Clark and Paula Gunn Allen. "Earthly Relations, Carnal Knowledge: Southwestern American Indian Women Writers and Landscape." "Yellow Woman”: Leslie Marmon Silko. Ed. Melody Graulich. New Brunswick: Rutgers University Press, 1993: 115-150.

Smith, Linda Tuhiwai. Decolonizing Methodologies: Research and Indigenous Peoples. Dunedin: University of Otago Press; London: Zed Books, 1999.

---. "In search of a language and a shareable imaginative world: e kore taku moe e riro i a koe." Feminist Thought in Aotearoa/New Zealand: Differences and Connections. Eds. Rosemary Du Plessis and Lynne Alice. Auckland: Oxford University Press, 1998. 95-103.

---. Mana Wahine - Mana Maori: A Case Study. Auckland: Maori Education Research and Development Unit University of Auckland, 1990.

Stead, C.K. "Keri Hulme's The bone people and the Pegasus Award for Maori literature." Ariel 16.4 (Oct. 1985): 101-108.

Szászy, Mira. From Me Aro Koe ki te Ha o Hineahuone. Te Ao Marama 2 Regaining Aotearoa: Maori Writers Speak Out. Ed. Witi Ihimaera. Auckland: Reed Publishing, 1993. $287-291$.

Teaiwa, Katerina Martina. "Our Sea of Phosphate: The Diaspora of Ocean Island." Indigenous Diasporas and Dislocations. Eds. Graham Harvey and Charles D. Thompson Jr. Aldershot: Ashgate Publishing Limited, 2005.

Te Awekotuku, Ngahuia. Mana Wahine Maori: Selected Writings on Maori Women's Art, Culture and Politics. Auckland: New Women's Press, 1991.

Thaman, Konai Helu. "Of Daffodils and Heilala: Understanding (Cultural) Context in Pacific Literature." Navigating Islands and Continents: Conversations and Contestations in and around the Pacific. Eds. Cynthia Franklin, Ruth Hsu and Suzanne Kosanke. Honolulu: College of Languages, Linguistics and Literature, University of Hawai'i and the East-West Center. 2000. 40-50.

Trask, Haunani-Kay. "Writing in Captivity: Poetry in a Time of De-Colonization." Navigating Islands and Continents: Conversations and Contestations in and around the Pacific. Eds. Cynthia Franklin, Ruth Hsu and Suzanne Kosanke. Honolulu: College of Languages, Linguistics and Literature, University of Hawai'i and the East-West Center. 2000. 51-55.

Treadwell, Greg. Rev. of Strands, by Keri Hulme. Stamp 31 (1992): 30-31.

Wedde, Ian. "Trying to make sense." Rev. of Lost Possessions, by Keri Hulme, and Te Kaihau/The Windeater by Keri Hulme. Listener 31 May 1986: 35. 
---. Rev. of Lost Possessions, by Keri Hulme. Wellington City Magazine (April 1986):74-5.

Wendt, Albert. "Towards a New Oceania." A Pacific Islands Collection: Seaweeds and Constructions 7 (1984): $71-85$.

Weston, Tom. "Poets who seek truth." Review of Beyond by Brian Turner and Stones in Her Mouth, by Roma Potiki. Press 1 May 1993: Sup10.

Whitcoulls List - Top 100 Books in New Zealand. Whitcoulls. 1 Apr. 2006. $<$ http://www.whitcoulls.co.nz/top100.asp?storeurl=whitcoulls $>$.

Williams, Mark. Leaving the Highway: Six Contemporary New Zealand Novelists. Auckland: Auckland University Press, 1990.

Wilson, Janet. "Hulme's maturing talent." Rev. of Strands, by Keri Hulme. Evening Post13 Mar. 1992: 5.

Wood, Briar. "I need no definition.” Int. with Roma Potiki. Hecate 21.1 (May 1995): 58-63.

Womack, Craig S. Red on Red: Native American Literary Separatism. Minneapolis: University of Minnesota Press, 1999. 